\title{
ECONOMICS
}

\section{CHINA AND GLOBAL MACROECONOMIC INTERDEPENDENCE}

\author{
by
}

\section{Rod Tyers}

Business School

University of Western Australia and Research School of Economics

Australian National University 


\title{
CHINA AND GLOBAL MACROECONOMIC INTERDEPENDENCE
}

\author{
Rod TYERS
}

Revised March 2015

\section{DISCUSSION PAPER 15.05}

\begin{abstract}
China is transitioning toward more inward-focussed growth, causing adverse changes in the product and financial terms of trade in the advanced economies. At the same time, international financial markets tussle between tightening forces associated with the US recovery on the one hand and unconventional monetary expansion in Europe and Japan on the other. The way these shocks interact is examined in this paper using a global macro model with national portfolio rebalancing and asset differentiation and a representation of unconventional monetary policy. Results are found to be sensitive to the contributions of productivity and capital accumulation to China's growth. When these are offered in realistic combination, the combined shocks are deflationary in the US and China, implying that contractionary US monetary policy is not imminent. Monetary responses in the US and China then combine with price targeting regimes in the EU and Japan to expand liquidity globally, amplifying impacts on financial markets and the global distribution of real investment.
\end{abstract}

Key words: Global performance; US recovery; China’s transition, macro interdependence, financial integration

* Business School, University of Western Australia, and Research School of Economics, Australian National University. Funding for the research described in this paper is from Australian Research Council Discovery Grant No. DP0557885. Useful discussions on the topic with Dong He, Bert Hoffman, Song Ligang, Paul Luk, Dai Mi, Peter Robertson, Wenlang Zhang and Peter Warr are acknowledged, along with comments received at seminars at the China Center for Economic Research, Peking University, the Hong Kong Institute of Monetary Research and the Australian National University. Thanks for assistance with data gathering for this research are due to Ying Zhang Tsun Se Cheong and Kazuki Tomioka. 


\section{Introduction}

Central to understanding the behaviour of the global economy is the interaction between the macroeconomic policy regimes of the major economic regions, the US, the Western Europe and Japan, recently joined by China. These regions are all "large" in that the policies of each affect the others as a group as well as the world's many smaller economies. Their behaviour is therefore highly inter-active and strategic. The rise of China and other Asian, heretofore developing, economies since the 1980s has not only underwritten global economic performance but high East Asian saving rates have contributed to what became known as the Asian "savings glut". ${ }^{1}$ Global real interest rates peaked in the mid-1980s and have fallen since, in part because of this relative increase in global savings supply, though more recently because of unconventional monetary policy, principally in the US and Japan (He and McCauley 2013, Arora et al. 2014).

This pattern of interaction with Asia began to change, first with the slowdown in Japan in the 1990s but more recently with the poor performance of the other large regions. It has become clear that the export-led growth model is unsustainable for China, for three main reasons. First its light manufacturing exports now loom large in global trade and there is insufficient market growth for their expansion to continue. Second, a demographic contraction is imminent that will eventually reduce the availability of surplus agricultural workers, raising labour costs and slowing productivity growth. And third, reforms that will help continue China's high growth rate must now venture into the heavy manufacturing and services sectors, which are oligopolistic, and therefore not the vanguard of future growth (Aghion et al. 2013), and which have, in any case, not been export oriented. A "turn inward" is required that is therefore politically difficult. For these reasons slower growth is likely, not only in China but also in those Asian economies that depend on its market for manufacturing components. ${ }^{2}$ Moreover, Asia's contribution to global saving will also decline as reforms ensure that Chinese households are offered the choice to consume from more of their corporate income and as populations age, particularly in China and Japan. ${ }^{3}$

This change presents both opportunities and dangers in the advanced economies. On the one hand, rising Chinese consumption could be one of the Keynesian stimuli required to raise demand and reduce unemployment queues in the advanced economies. On the other, it will

\footnotetext{
${ }^{1}$ See Bernanke (2005), Chinn and Ito (2007), Choi et al. (2008), Ito (2009) and Tyers (2015b).

${ }^{2}$ For details on the extent of production fragmentation and networking in Asia, see Athukorala (2011).

${ }^{3}$ For a comprehensive analysis of Asian household saving, see Horioka and Terada-Hagiwara (2012), and for discussion of China's high corporate saving see Kuijs (2006), Tyers and Lu (2008).
} 
place upward pressure on global interest rates. Private portfolios that have tended to hoard money during deflationary times will eventually rebalance and central banks will need to soak up liquidity, including by shedding the non-traditional assets acquired via unconventional monetary policy (UMP). This will raise interest rates in both long and short maturity bond markets. Because the long instruments are extensively traded internationally, and held by Asian savers whose excess demand for them will decline, the rise in financing costs could be very sharp.

This comes at a time when a recovery in the US economy has led to the declared abandonment of US UMP and when an expected (and actual) appreciation of the US\$ raises investment demand there. Meanwhile Japan and Europe are maintaining, and Europe will bolster, the global liquidity flood. Low interest rates in Europe and Japan, combined with the US appreciation, would suggest still lower rates in the US, militating against a US tightening. In this context it is possible that the change in China's growth regime, which is unleashing of its consumption, could yield the offsetting financial tightening force required. Clearly, these many shocks point in different directions, clouding vision of the eventual trends in economic performance and financial behaviour.

To explore the interaction of shocks emerging in the major economic regions, a parsimonious global macroeconomic model is introduced that incorporates bilateral linkages across six regions via both trade and financial flows. It includes a number of innovative elements. First, although it is deterministic, by allowing for asset differentiation it incorporates optimising financial portfolio management in each region that serves to direct saving from each into investments across all regions. Second, the degree of asset differentiation is quantified to reflect financial integration that differs by region. Third, long maturity assets are focal and unconventional monetary policy (UMP) places direct demands on the global markets for these assets that are endogenous to chosen targets. This tends to enhance the spill-over effects of monetary policy (Chen et al. 2014), which proves important because China's growth surge was deflationary abroad, necessitating monetary expansion despite slow growth, while its transition shock is, by contrast, inflationary abroad.

Simulation results are found to be sensitive to the contributions of productivity and capital accumulation to China's growth in ways that end up consistent with old assertions about the sources of Chinese growth (Krugman 1994) and about the effects of it on US employment (Krugman 2010, Rodrik 2010). When productivity and capital growth are offered in realistic combination, the collective shocks are deflationary in the US and China, implying that 
contractionary US monetary policy is not imminent. Monetary responses in the US and China then combine with price targeting regimes in the EU and Japan to expand liquidity globally, amplifying impacts on financial markets and the global distribution of real investment. In the end, however, current year real effects of the change to China's growth regime prove to be modest. In the section to follow a review is offered of changes in China's relative size and the associated domestic transitions that presage its reduced excess saving. Section 3 then briefly discusses recent macroeconomic developments in the advanced economies. The model used for quantitative analysis is then presented in Section 4 and simulation results are described in Section 5. Conclusions are offered in Section 6.

\section{China's Transition and its Financial Effects Abroad}

China's unadjusted share of global GDP is now greater than Japan's and its shares of global exports, saving and investment are larger than those of the US and similar to those of the EU (Table 1). The implications of this rapid expansion in output and trade for the large economic regions have been the subject of considerable debate. On the positive side are global benefits in the form of a terms-of-trade improvement (cheaper light manufactured imports relative to exported luxury and capital goods). On the negative side, is the relocation of light manufacturing from the advanced economies to China and an associated contraction in the demand for low-skill labour. On macroeconomic policy, there has been criticism of China, focusing on its current account surplus and perceived exchange rate distortions. This debate has centred on the "growth surge" period between China's WTO accession and the GFC. ${ }^{4}$ But that controversial period is now passed and China is in "transition" toward more inwardsourced growth that is tending to unpick the growth surge shocks.

The growth surge

During this period consumption fell short of output growth, causing substantial surplus production and the consequent current account surplus "lense" illustrated in Figure 1. As incomes and wealth increased, outward capital controls prevented diversification of private portfolios abroad and so the excess saving went abroad in the form of accumulating official foreign reserves. The majority of this accumulation was in long maturity US Treasury

\footnotetext{
${ }^{4}$ The American perspective on the growth surge period is offered by Bergsten et al. (2008) and Lardy (2006, 2012), while the case against the "currency manipulator" charge is made by, amongst others, Tyers and Zhang (2011). The advanced resource economies like Australia and Canada all enjoyed undisputed gains from China's rise, via their raw material exports. Asian neighbors were hurt by China's export competition in the early stages but helped in the later stages as China became a major destination for component exports (Athukorala 2011).
} 
instruments (Beltran et al. 2012)). This bolstered the continuing effects of the global refocussing of income generation into the high-saving Asian economies, which had commenced in the 1980s and which had already accelerated the rate at which the global savings supply curve was advancing. With slower growth in the advanced regions, global investment demand was comparatively slow, causing a decline in the Wicksellian (1898) "natural” rate of interest at the global level. ${ }^{5}$

\section{Financial implications}

Consistent with the segmentation theory of the yield curve (Johnson et al. 2010), long rates are not merely the commonly claimed (Borio and Disyatat 2011) expectational extensions of short policy rates. The transaction cost of financing long term investments via a succession of short contracts is prohibitive, allowing short and long maturity instruments to trade at prices and yields that differ beyond what would be expected from time preference and expectations forces (Shiller et al. 1983, He and McCauley 2013). Short bonds primarily serve domestic financial sectors and are instruments of conventional domestic monetary policy. Movements in their yields show their clear links to region-specific business cycles. Long bonds, by contrast, arbitrage with the major instruments of private saving and investment and are extensively traded internationally. Their yields tend therefore to be more stable through time than business-cycle driven short yields and reflect movements in the equilibrium between global saving and investment.

He and McCauley (2013) find evidence of "imperfect substitutability along the yield curve" and use it to explore monetary policy spill-over effects, which they see as enlarged by the global integration of long bond markets. Ito (2013: 8) offers support for this view. He argues that as a result of financial globalisation, domestic financial markets are more susceptible to international factors and that tends to decouple short-term and long-term rates. Consistent with Bernanke (2005), he concludes that the long-term interest rate is tied down by global saving imbalances and hence reflects the natural rate of interest. This reasoning, and that of Rey (2013), both imply that, when there is free capital mobility, there is inter-regional arbitrage at the long end of the yield curve whereas the short end of the yield curve is conventionally controlled by monetary authorities. Support for this international arbitrage at the long end, and for the weight of Chinese and other Asian saving, is suggested by the time paths of the

\footnotetext{
${ }^{5}$ Ex ante shifts in saving supply and investment demand cannot be observed. See Tyers (2015b) for a discussion of the available data.
} 
advanced region long yields in Figure 2, which are smoother through time than short yields and have trended downward. ${ }^{6}$

\section{The transition}

China's excess production and saving during the growth surge period conferred on the advanced economies not only gains in their product terms of trade but also in their financial terms of trade. As the recent trends in Figure 1 attest, however, these surpluses are now in continuous decline. Indeed, the domestic focus on growth via light manufacturing exports has stalled as China has come to dominate these industries at the global level and as the domestic supply of excess rural labour has begun to dry up. ${ }^{7}$ There is therefore wide agreement that its growth will, and should, be increasingly underpinned by rising home consumption rather than exports. ${ }^{8}$ Superficially, it would seem that a switch to domestically driven growth should be possible, just by consuming more and exporting less. But this simple idea is problematic because the export led growth strategy focusses production on light manufacturing, while China's growing middle class demands sophisticated manufactures and high quality services that include transport, telecommunications, health and education, all of which are supplied by oligopolistic industries that accumulated considerable rents during the growth surge and directed these into corporate saving, bolstering the current account surplus. ${ }^{9}$ To diversify China's output toward these products requires politically difficult policy reforms, not to mention continued investment in human capital and infrastructure. While the potential is there (Tyers 2014), and the anecdotal evidence suggests the reforms are occurring, overall growth has slowed. China's new "transitional” growth regime can therefore be characterised as offering reduced rates of productivity and capital accumulation and continuing declines in excess saving.

\footnotetext{
${ }^{6}$ The separation of the series for Japan is associated with its long term current account surplus and the major Yen appreciation shocks of the late 1980s and early 1990s, which established a negative risk premium amongst Japanese savers. In all regions, inflation rates were low throughout the period shown in the figure and so the trend of nominal long rates reflects that of corresponding real rates. For formal analysis of the integration of these long bond markets see Arora et al. (2014).

${ }^{7}$ The timing of China's Lewis turning point is a subject of controversy, as suggested by the contrasts between the views expressed by: Cai (2010), Garnaut (2010) and Golley and Meng (2011), which offer just a sampling of a substantial literature. There is, however, little doubt that the turning point is on its way, even if there is little agreement as to whether recent real wage rises suggest its presence.

${ }^{8}$ For the Chinese official line on the "rebalancing” of its economy, including its external accounts, see Wen (2007, 2011).

${ }^{9}$ For analysis of the greater growth potential in competitive relative to oligopolistic markets, see Aghion et al. (2013) and Aghion et al. (2014). Oligopoly rents in China are linked to corporate saving (Kuijs 2006, Song et al. 2011), last measured in the region of a fifth of GDP.
} 


\section{Developments in the Advanced Regions}

Global financial markets continue to be dominated by the US, which has sustained a structural current account deficit since the 1990s. Though much that has been unpalatable since 2007 has been blamed on the GFC, the broad pattern of international finances did not appear to be permanently changed by it. Critically, it brought about a reversion by the private sectors in the US, the EU and Japan to net saving positions while all three governments assumed net borrowing positions. ${ }^{10}$ It therefore replaced private debt, some of which had been unsustainable, with sovereign debt, some of which is also unsustainable, leaving heightened global uncertainty as to sovereign financing. ${ }^{11}$

\section{Bond yields and UMP}

A key change took place around 2005, before which the large US deficit had been financed by surpluses in Japan and the oil producing countries. Thereafter, however, the burden of this financing rested increasingly with China, whose dollar contribution became the single largest in 2005 and peaked in 2008 (Tyers et al. 2013). After 2010, however, China’s relative role as surplus financer began to diminish with the shifts in its domestic saving-investment balance already discussed. It remains the world's largest single national buyer of US debt and equities, however, highlighting the potential for disruption in US financial markets should China's excess saving continue to decline (McKinnon 2013).

As Figure 2 indicates, the downward trend in long yields in all three advanced economies persisted beyond the peak of China's bond purchases, as central bank buying took over with expansionary monetary policies, including the implementation of UMP in Japan, the US and the UK. For economies that have been comparatively stagnant in real terms since 2007, central bank asset holdings rose immensely, quadrupling in the US, almost quadrupling in the UK and doubling with more to come in the "Eurosystem" and Japan (He and McCauley 2013). ${ }^{12}$ These purchases raised the prices of long bonds and related instruments and suppressed their yields. Unlike more conventional monetary policy, the high spill-over rate of UMP forces the domestic monetary cycle beyond national borders with immediacy. When implemented at home it causes private financial outflows as investors seek out better yields abroad and these

\footnotetext{
${ }^{10}$ For analysis of this see Tyers et al. (2013).

${ }^{11}$ According to the OECD Economic Outlook 89 Database, the sovereign debt stock problems of continental European economies and Japan predated the GFC though they were exacerbated by it. The largest proportional impacts of the GFC were to the US and the UK. Even so, though these countries' debt stock to GDP ratios became not significantly larger than that of France and are dwarfed by those of Portugal, Italy, Greece and Japan. ${ }^{12}$ It is notable that China's central bank assets are large compared with the others, due to reduced money creation by China's commercial banks in response to high reserve to deposit ratios.
} 
appreciate foreign currencies, threatening deflation and inducing expansionist responses. In part for this reason, expansionary monetary policy has spread across the three large blocs. ${ }^{13}$

\section{The US recovery and the liquidity flood}

During 2014, US-triggered tightening was commonly anticipated in global financial markets.

This in turn was seen as being likely to place downward pressure on prices of stocks and other assets. The Fed resorted to $\mathrm{UMP}^{14}$ on the expectation that this would raise the monetary base sufficiently to tame deflationary forces, to induce a more healthy demand for productive assets and, ultimately, to reduce the rate of unemployment. In the third phase, entitled QE3, this took the form of open-ended purchases at a rate of $\$ 85$ bn per month delimited only by the prospect of the US unemployment rate eventually falling below six per cent.

In mid-2013 it was announced that this buying program would be "tapered" over the year to come. The effect of this was to stimulate a private scramble out of long bond holdings that saw their yields rise from below two per cent to three per cent in a few months. This was referred to as the "taper tantrum". But the Fed bond purchases continued and yields stabilised again. The announced taper actually began in December 2013 and, as the unemployment rate fell below six per cent, it ended with a final \$15 bn purchase in October 2014. To the time of writing there has been no further "tantrum". The path of long term interest rates has shown no tendency toward a lasting increase. How can purchases at such a high rate cease without causing the price of these globally significant bonds to fall and hence their yields to rise?

There are many possible explanations. ${ }^{15}$ Central are those relating to the US recovery and the comparatively poor performances of the European and Japanese economies. Higher growth in the US, combined with the declared end of US UMP, generates greater expected returns and this attracts private financial inflows. These, in turn, tend to appreciate the US\$, inducing central banks in other regions (especially in China and Japan) to rebalance their portfolios toward US Treasuries. The nominal effective US exchange rate has indeed appreciated, by almost six per cent in the second half of 2014. While concrete data on very recent foreign

\footnotetext{
${ }^{13}$ UMP on the part of the US Federal Reserve was that the substitution would be away from US bonds to US equities. And this has happened too. It is this arbitrage that has sustained continued rises in market capitalization since the GFC.

${ }^{14}$ This comprised acquisitions of a combination of long term Treasury bonds and mortgage backed securities, the former dominating in the early phases and the latter more recently

${ }^{15}$ One claim is that the credibility of the US commitment to ending QE is doubtful, but the December 17 Federal Reserve Statement on Monetary Policy indicates that dissenting board members preferring not to rule out a return to QE were out-voted by a clear majority. Another is that, with the gradual narrowing of the US fiscal deficit, the supply of long term Treasuries has declined. This is a possible contributor, though US government financing requirements remain considerable.
} 
purchases of US Treasuries is not yet available, there are further reasons to expect such purchases to have increased recently. China is the largest single foreign holder of US Treasuries and it has a clear interest in sustaining their value.

In the case of Japan, also a large foreign holder, its own QE has been proceeding strongly under Abenomics, but it has caused Japanese short and long bond yields to fall near the zero lower bound. Further monetary expansion requires the acquisition by the Bank of Japan of other assets. Purchases of US Treasuries meet this requirement, with the complementary benefit that they further depreciate the Yen. Finally, there is the effect of the US real recovery on private US demand for Treasury bonds, and those assets that arbitrage closely with them. The volume of US private saving is increasing and some if it is chasing such assets.

Thus, while the US has, at least temporarily, ceased contributing less to the global liquidity flood, the European Central Bank is committed to UMP in 2015 and the Bank of Japan is showing no signs of tapering its corresponding program. These central banks are therefore taking up the slack and acquiring US assets in the process. While ever interest rates outside the US remain low for this reason, a US recovery that causes investors to expect an appreciating US\$ implies that US interest rates will tend to decline rather than to increase. The US real recovery and the struggle in Europe and Japan to break out of stagnation are therefore key global macroeconomic challenges. In what follows the changes in China's growth regime are considered in this context. The approach adopted is through the use of a global general equilibrium model. This approach also allows "counterfactual” analysis to separate out the roles of Chinese from other shocks. The most parsimonious model that will allow such an analysis is presented in the section to follow.

\section{Modelling Macro Interdependence}

A multi-region general equilibrium structure is used that centres on the global financial capital market. ${ }^{16}$ It is assumed that the financial products of each region are differentiated and that portfolio managers assign new net saving across regions so as to maximise expected portfolio returns given this differentiation. This retains Feldstein-Horioka (1980) home bias while allowing significant redirections in financial flows at the margin. It also allows the level of

\footnotetext{
${ }^{16}$ The model used is a more advanced variant on that used in Tyers (2015a). That model assumed a perfectly integrated global bond market and so tended to generate unrealistically large spill-over effects. Here, all financial products, including government bonds, are represented as regionally differentiated and so there is no perfectly integrated global market for any asset class. Also, this model introduces UMP explicitly.
} 
global financial market integration to be parameterised by varying the degree of differentiation. The scale of short run spill-over effects associated with growth performance, excess saving and monetary policy therefore depend on it.

Although there is a tendency for financial flows to move the global economy toward interest parity, in the length of run considered asset differentiation leaves this process incomplete. At the same time, regional rates of return on equity investments depart from regional bond yields, the former reflecting expected rates of return on installed capital and the latter short run equilibrium in regional financial markets between savers, indebted governments and investors. Within each region the demand for money is driven by a "cash in advance" constraint applying across the whole of GDP. For any one household, home money is held in a portfolio with long maturity bonds, which are claims over physical capital and government debt across the regions. ${ }^{17}$ On the supply side of the money market, in regions implementing UMP, expansions raise demand for long maturity bonds, reducing their yields and hence reducing the opportunity cost of holding money. ${ }^{18}$

Six regions are identified: the US, the EU, Japan, China, Australia and the Rest of the World, though the focus of this paper is on the first four. ${ }^{19}$ Each region supplies a single product that is also differentiated from the products of the other regions. On the supply side, there are three primary factors with "production" labour $(L)$ a partially unemployed variable factor while the stocks of physical capital $(K)$ and skill $(S)$ are fixed and fully employed. Collective households are net savers with reduced form consumption depending on current and expected future disposable income and the home interest rate. Aggregate consumption is subdivided via a single CES structure between the products of all the regions. The following offers detail on the aspects of the model central to this analysis. ${ }^{20}$

\section{Financial markets}

Here the modelling departs from convention by incorporating explicit portfolios of assets from all regions. Data on regional saving and investment for 2011 is first combined with that on international financial flows to construct an initial matrix to allocate total domestic saving in each region to investment across all the regions. From this is derived a corresponding matrix

\footnotetext{
${ }^{17}$ Expectations are exogenous in the model and are formed over future values of home nominal disposable income, the rate of inflation, the real rate of return on home assets and bilateral real exchange rates.

${ }^{18}$ By contrast, conventional monetary policy involves trade in short term instruments which has no direct impact on the market for long term bonds.

${ }^{19}$ The EU is modeled as the full 26 and it is assumed that this collective has a single central bank.

20 The more routine components of the model are shared with an earlier version that uses a somewhat less developed financial structure. See Tyers (2015a, Appendix 1).
} 
of initial shares of region i's net (private and government) saving that are allocated to the local savings supply that finances investment in region $j, i_{i j}^{s o}$. When the model is shocked, the new shares are calculated so as to favour investment in regions, $j$, with comparatively high expected after tax yields, implying high expected real gross rates of return, $r^{c e}$.

$$
r_{i}^{c e}=r_{i}^{c}+\hat{e}_{i}^{e}=\frac{P_{i}^{P} M P_{i}^{K}}{P_{i}^{K}}\left(\frac{\varphi_{i}^{0}}{\varphi_{i}}\right)+\hat{e}_{i}^{e},
$$

where $P_{i}^{K}$ is the price of capital goods, which in this model is $\gamma_{i} P_{i}^{P}$, where $\gamma_{i}$ is the price of capital goods relative to that of output, $P_{i}^{P}$, the producer price of the region's generic good. ${ }^{21}$ The (exogenous) expected proportional change in the real exchange rate is $\hat{e}_{i}^{e}$. A further adjustment is made using an interest premium factor, $\varphi_{i}$, that is defined relative to the US ( $\left.\varphi_{U S}=1\right)$. This permits consideration of the effects of changes in sovereign risk in association with the fiscal balance. Increments to regional sovereign risk cause investments in regions with increasing fiscal deficits to be less attractive.

$$
\varphi_{i}=\varphi_{i}^{0}\left[\left(\frac{G_{i}}{T_{i}} / \frac{G_{U S}}{T_{U S}}\right)\right]^{\phi_{i}}, \quad \forall i \neq " U S ",
$$

where $\phi_{i}$ is an elasticity indicating sensitivity to sovereign risk.

In region $i$, then, the demand for investment financing depends on the ratio of the expected real rate of return on installed capital, $r_{i}^{c e}$ and a domestic market clearing real bond yield or financing rate, $r_{i}$. It is real investment that responds to these real rates but the model tracks nominal investment expenditure. For this reason and adjustment is also needed for change in the price of capital goods.

$$
\frac{I_{i}^{D}}{I_{i}^{0}}=\frac{P_{K}}{P_{K}^{0}}\left(\frac{r_{i}^{c e}}{r_{i}}\right)^{\varepsilon_{i}^{I}},
$$

where $\varepsilon_{i}^{I}$ is a positive elasticity enabling the relationship to reflect Tobin’s Q-like behaviour. This investment demand is then matched in each region by a supply of saving that incorporates contributions from all regional households.

\footnotetext{
${ }^{21}$ The producer price level is the factory door price of the regional good, which differs in this model from the GDP price level, $P^{Y}$, due to indirect taxation and from the consumer price, $P^{C}$, which includes imported products. See Tyers (2015a: Appendix 1) for further explanation of this.
} 
Region $i$ 's portfolio manager allocates the proportion $i_{i j}^{S}$ of its annual (private plus government) saving to new investments in regions $j$, such that $\sum_{j} i_{i j}^{S}=1 .^{22}$ Because the newly issued equity is differentiated across regions based on un-modelled and unobserved regionspecific properties, their services are combined via a constant elasticity of substitution (CES) function specific to each regional portfolio manager. Thus, region i's household portfolio management problem is to choose the shares, $i_{i j}^{S}$, of its private saving net of any government deficit, $S_{i}^{D}=S_{i}^{P}+T^{D}+T^{I}-G$, which are to be allocated to the assets of region $j$ so as to maximise a CES composite representing the value of the services yielded by these assets:

$$
\max _{\substack{i_{i j}^{S} \\ u_{i}}} U_{i}^{F}=S_{i}^{D}\left[\sum_{j} \alpha_{i j}\left(i_{i j}^{S}\right)^{-\rho_{i}}\right]^{-\frac{1}{\rho_{i}}} \text { such that } \sum_{j} i_{i j}^{S}=1 \text {. }
$$

Here $\alpha_{i j}$ is a parameter that indicates the benefit to flow from region $i$ 's investment in region $j$. The CES parameter, $\rho_{i}$, reflects the preparedness of region $i$ 's household to substitute between the assets it holds. To induce rebalancing in response to changes in rates of return the $\alpha_{i j}$ are made dependent on ratios of after-tax yields in destination regions, $j$, and the home region, $i$, via: ${ }^{23}$

$$
\alpha_{i j}=\beta_{i j}\left(\frac{r_{j} / \tau_{j}^{K}}{r_{i} / \tau_{i}^{K}}\right)^{\lambda_{i}} \quad \forall i, j, \quad \lambda_{i}>0 \quad \forall i
$$

Here, $\tau_{i}^{K}$ is the power of the capita income tax rate in region $i$. This relationship indicates the responsiveness of portfolio preferences to yields, via the (return chasing) elasticity $\lambda_{i}$. The allocation problem, thus augmented, is:

$$
\max _{i_{i j}^{S}} U_{i}^{F}=S_{i}^{D}\left[\sum_{j} \beta_{i j}\left(\frac{r_{j} / \tau_{j}^{K}}{r_{i} / \tau_{i}^{K}}\right)^{\lambda_{i}}\left(i_{i j}^{S}\right)^{-\rho_{i}}\right]^{-\frac{1}{\rho_{i}}} \text { such that } \sum_{j} i_{i j}^{S}=1 \text {. }
$$

Solving for the first order conditions we have, for region $i$ 's investments in regions $j$ and $k$ :

\footnotetext{
${ }^{22}$ The manager does not re-optimise over total holdings every year. This is because the model is deterministic and risk is incorporated only via exogenous premia. The motivations for continuous short run rebalancing, other than the arrival of new saving, are therefore not represented.

${ }^{23}$ Note that region i's market bond yield, $r_{i}$, is determined concurrently and indicates the replacement cost of capital in region $i$ and therefore the opportunity cost for region $i$ 's household of investment in region $j$.
} 


$$
\frac{i_{i j}^{S}}{i_{i k}^{S}}=\left(\frac{\beta_{i j}}{\beta_{i k}}\right)^{\frac{1}{1+\rho_{i}}}\left(\frac{r_{j} / \tau_{j}^{K}}{r_{k} / \tau_{k}^{K}}\right)^{\frac{\lambda_{i}}{1+\rho_{i}}}
$$

This reveals that region i's elasticity of substitution between the bonds of different regions is $\sigma_{i}^{I}=\lambda_{i} /\left(1+\rho_{i}\right)>0$, which has two elements. The return-chasing behaviour of region $i$ 's household $\left(\lambda_{i}\right)$ and the imperfect substitutability of regional bonds, and therefore the sluggishness of portfolio rebalancing $\left(\rho_{i}\right)$. For the purposes of this analysis the values of $\sigma_{i}^{I}$ are seen as indicating the extent of each region's integration with global financial markets. The optimal share of the net domestic saving of region $i$ that is allocated to assets in region $j$ then follows from (8) and the normalisation condition, that $\sum_{k} i_{i k}^{S}=1$ :

$$
i_{i j}^{S}=\frac{1}{\sum_{k}\left(\frac{\beta_{i k}}{\beta_{i j}}\right)^{\frac{\sigma_{i}^{I}}{\lambda_{i}}}\left(\frac{r_{k} / \tau_{k}^{K}}{r_{j} / \tau_{j}^{K}}\right)^{\sigma_{i}^{I}}} .
$$

The key matrix for calibration is $\left[\beta_{i j}\right]$. These elements are readily available, first, by noting that only relative values are required and hence, for each region of origin, $i$, one value can be set to unity, and second, by making the assumption that the initial database has the steady state property that the net rates of return in regions $j$ are initially the same as the market bond yield, $r_{j}$. Then, since in the base data $r_{i j}^{e 0}=r_{j}^{0}, r_{i k}^{e 0}=r_{k}^{0}$, the $\beta_{i j}$ s are available from a modified (6):

\section{Regional money market equilibrium}

A cash-in-advance constraint is assumed to generate transactions demand for home money across all components of GDP. The opportunity cost of holding home money is set at the nominal after-tax yield on home long term bonds. ${ }^{24}$ Real money balances are measured in terms of purchasing power over home products.

$$
m_{i}^{D}=a_{i}^{M D}\left(y_{i}\right)^{\varepsilon_{i}^{M Y}}\left(\frac{r_{i}\left(1+\pi_{i}^{e}\right)}{\tau_{i}^{K}}\right)^{-\varepsilon_{i}^{M R}}=\frac{M_{i}^{S}}{P_{i}^{Y}}=\frac{\eta_{i} M_{i}^{B}}{P_{i}^{Y}} .
$$

\footnotetext{
${ }^{24}$ Thus, it is assumed here that the opportunity cost of holding money is measured by the long bond yield, which is the dominant determinant of non-money portfolio yields. Short rates, at least as they have a role in conventional monetary policy, are here embedded in the determination of the monetary base. While housing investment can be sensitive to short rates in economies where most mortgage contracts have variable rates, the assumption that investment financing depends on the long maturity market is accurate in a comparative sense and it is a useful abstraction.
} 
Here $y$ is real regional GDP, $P^{Y}$ is the GDP price and $\pi_{i}^{e}$ is the expected inflation rate of the consumer price level, $P^{C}$, defined as a CES aggregate of home and imported consumer prices. ${ }^{25}$ The money multiplier is $\eta_{i}$ and $M_{i}^{B}$ is the monetary base. ${ }^{26}$ The monetary base, $M^{B}$, can be set as an exogenous policy variable or as endogenous to a price level or exchange rate target.

\section{Regional financial market clearance}

The home financial market in each region clears separately. For region $i$, the nominal value of domestic investment, $I_{i}^{D}$, represents the sum total of all domestic long bond issues. This is then equated with demand for those bonds from home and foreign (net private and government) savings, along with demands for home long bonds that arise from the “quantitative easing” components of monetary expansions by both home and foreign central banks.

Total investment spending in region $i$, in i's local currency, is then:

$$
I_{i}^{D}=\sum_{j}\left(\left[i_{j i}^{S} S_{j}^{D}+\theta_{j i}^{Q E} S_{j}^{Q E} \Delta M_{j}^{B}\right] \frac{E_{j}}{E_{i}}\right), \quad \forall i,
$$

where $E_{i}$ is the nominal exchange rate of region $i$ relative to the US\$, which is the numeraire in the model $\left(E_{U S}=1\right)$. The "quantitative easing" component of the current period's expansion of the monetary base by region $j$ 's central bank, $s_{j}^{Q E}$, and the share of this expansion that takes the form of acquisitions of region $i$ 's long bonds, $\theta_{j i}^{Q E}$, both determine central bank demand. These flows are originally in foreign currency and are therefore converted at the appropriate cross rates. The regional real bond yields (interest rates, $r_{j}$ ) emerge from this equality. Their convergence across regions is larger the larger are the elasticities of asset substitution, $\sigma_{j}^{I}$.

\section{Balance of payments}

The sum of net inflows of payments on the current account and net inflows on the capital and financial accounts, measured in a single (home) currency is zero:

$$
X_{i}-M_{i}+\sum_{j \neq i}\left(\left[i_{j i}^{S} S_{j}^{D}+\theta_{j i}^{Q E} s_{j}^{Q E} \Delta M_{j}^{B}\right] \frac{E_{j}}{E_{i}}\right)-\sum_{j \neq i}\left(i_{i j}^{S} S_{i}^{D}+\theta_{i j}^{Q E} s_{i}^{Q E} \Delta M_{i}^{B}\right)=0, \quad \forall i \neq " U S "
$$

\footnotetext{
${ }^{25}$ For details of the specification of consumption and price aggregates, see Tyers (2015a, Appendix 1).

${ }^{26}$ In this study the money multiplier is held constant. In applications to financial shocks, however, it falls as confidence in financial institutions declines and those institutions hold more liquid reserves.
} 
The second two terms in (12) are financial inflows and outflows. The first parenthesised term represents acquisitions of region $i$ 's home-issued long bonds by foreign savers and by foreign central banks, the latter associated, as above, with the "quantitative easing" component of the current period's expansion of the monetary base in each region. These net saving and central bank flows are originally in foreign currency and so are converted at the appropriate cross rates. The second represents acquisitions of foreign-issued long bonds by region $i$ 's home savers and its own central bank. ${ }^{27}$ A balance of payments in the US is implied by balance in all the other regions. These equations determine the nominal exchange rates and, since these are defined relative to the US\$, that for the US is always unity $\left(E_{U S}=1\right)$.

\section{Model database, parameters and operation}

The model database is built on national accounts as well as international trade and financial data for the global economy in 2011. As indicated previously, the scale of the Chinese and advanced economies is indicated in Table 1. Of particular interest here are the financial flows between these regions, the pattern of which is suggested in Table 2. It is noteworthy that, while the share of China's trade in goods is larger with Europe than the US, the share of the US in its bilateral financial flows is comparatively high while that of Europe is low. ${ }^{28}$ These differences prove important in the results that emerge from the modelling.

\section{Analysis}

The model is first applied to the international significance of the sources of China's growth. This issue stems from the debates over whether China's growth has primarily depended on capital accumulation on the one hand or productivity on the other and the associated debate on the extent to which its growth has displaced employment in the advanced economies. It is confirmed that the sources of growth matter for international impacts but that the results are not as simple as some of the rhetoric. The second application is to the magnitudes of the international impacts of China's growth regimes in the context of other landmark changes to the global economy, namely the US real recovery and the continuing European and Japanese monetary expansions.

\footnotetext{
${ }^{27}$ The nominal values of imports and exports, $M_{i}$ and $X_{i}$, are formulated in Tyers (2015a, Appendix 1).

${ }^{28}$ Further details as to the sources and construction of the database can be obtained from Tyers (2015a, Appendix 2).
} 


\subsection{Implications of the source of China's growth}

Krugman (1994) is amongst those who have, at various times, claimed that China's growth has been driven by capital accumulation rather than productivity growth. At the same time, many have claimed that the global economic integration that has facilitated China's growth has facilitated "job-stealing” from the advanced economies. ${ }^{29}$ Superficially at least, job stealing would seem more likely to stem from productivity shifts in China because it adds effective workers to the global economy, driving down the global wage or the employment level outside China. Alternatively, it can be seen as sucking in investment and thereby reducing growthenhancing investment expenditure in the advanced regions. A growth path driven by capital accumulation only, however, would reduce China's rate of return and drive investment back to the US, raising demand there and so benefiting US workers. The simulation results differ from these simple scenarios because of the different real exchange rate and monetary effects of these shocks. The labour market and fiscal policy closures adopted for this purpose are given in Table 3. To make it clear whether the effects of Chinese growth are inflationary or deflationary abroad, the monetary target is assumed to be the monetary base in all regions. The results are summarised in Table 4.

\section{Productivity driven growth: effects on China}

This does direct investment to China, where the new investment demand drives up real interest rates globally. By itself, the reallocation of investment globally would cause a real appreciation in China but here it does not because of the primary effect of the productivity shock in reducing home costs. The result is a modest real depreciation. In China's money market, where no new price level changes are anticipated, the higher interest rate tends to reduce money demand but this is more than offset by growth in transactions demand from the productivity gain. The net effect, while the monetary base is held fixed, is a deflation. The combination of a real appreciation with the domestic deflation requires a nominal appreciation. While the deflation creates a drag on employment growth, the productivity change and the new investment ensure that there is a net real expansion, both in terms of real GDP and the real purchasing power of income.

\footnotetext{
${ }^{29}$ See, for example, Rodrik (2010), Helpmann et al (2010), Haskell et al. (2012), Autor et al. (2013) and Di Giovanni et al. (2013). Krugman (2010) declares, in a blog, that "China is making all of us poorer".
} 
The outflow of investment into China from the US is larger than that from either the EU or Japan and so the US experiences a real appreciation relative to China but real depreciations relative to the EU and Japan. Global financial integration ensures that its real interest rate also rises and, without any real shock to drive transactions demand for money, this causes a modest inflation. The correspondingly modest real exchange rate change, combined with the domestic inflation, implies a nominal depreciation. With the inflation comes increased employment and rises in both real GDP and the home purchasing power of US income. ${ }^{30}$ Nonetheless, the loss of US investment must eventually slow growth there.

\section{Capital driven growth: effects on China}

Consistent with the simple scenario outlined earlier, more Chinese capital reduces its rate of return and this directs investment out of China, tending to depreciate its real exchange rate. Importantly, however, the increased capital stock reduces Chinese production costs. These two effects here reinforce one another and so the Chinese real depreciation is larger than in the case of productivity driven growth. Because Chinese saving is reallocated abroad where expected rates of return are now higher, real interest rates tend to fall both at home and abroad. ${ }^{31}$ The home real interest rate decline boosts money demand and this is reinforced by the rise in transactions demand due to the capital-driven rise in output and income. With fixed money supply this causes a larger deflation than occurs in the productivity shock case. But the real depreciation is larger too, sufficient to accommodate both the deflation and a nominal depreciation. The deflation reduces labour demand, placing a drag on real output, which still rises because of the capital stock expansion. The real purchasing power of Chinese income falls, however. This is because China's consumer prices deflate by less than its GDP price since, at the reduced nominal exchange rate, the cost of purchasing foreign goods holds up.

\section{Chinese capital driven growth: effects on the US}

In this case there is an inflow of investment from China, which causes a real appreciation relative to the rest of the world. The global interest rate falls with the excess supply of Chinese saving. ${ }^{32}$ In the US money market there is no major shift in transactions demand and so, with a fixed money stock, this causes a deflation. This, combined with the real appreciation, implies a

\footnotetext{
${ }^{30}$ These effects suggest a monetary tightening response, which would eliminate the nominal depreciation and the domestic inflation, though this would also eliminate the employment and real GDP gains.

${ }^{31}$ This is with the single exception of the EU, which behaves differently because it has less capital market interaction with China than either the US or Japan.

${ }^{32}$ Again, the EU is an exception here because of its smaller financial exchanges with China.
} 
nominal appreciation which is moderated by the fact that the US deflation tends to be smaller than in other regions. The deflation, in turn, reduces labour demand and contracts real GDP. ${ }^{33}$ At the same time the real appreciation ensures that the real purchasing power of US income rises and, in any case, US growth is a beneficiary of increased investment.

\section{Reprise on growth sources}

The results suggest that the US would gain employment in the short run, though lose investment, in the event that China's growth is productivity driven. On the other hand, it would lose employment in the short run, but gain investment, were China's growth to be driven by capital accumulation. These conclusions cut against the simple logic that follows the flow of investment but ignores monetary and exchange rate effects. But they tie together the early assertions that China's growth was capital driven and that it caused labour displacement in the US and other advanced regions.

\subsection{The effects of Chinese growth in the context of other global macroeconomic change}

At the time of writing the most important change in the global macro-economy is the real recovery in the US. Long awaited since the GFC, this recovery leads the older advanced economies and it has brought an uptake in employment combined with GDP growth at its strongest level for a decade. Here this is represented by three shocks: to total factor productivity, to the relative cost of capital goods and to the scale of UMP. These shocks, listed in Table 5, are not founded on empirics but they are sufficient to yield a representative real US growth rate of between three and four per cent. In Europe and Japan the most significant macro-economic developments are upscale monetary expansions via UMP. These are seen to address deflationary expectations and are designed to yield two per cent consumer price inflation. Again, these shocks, which are also listed in Table 5, are not empirically based but they are structured to deliver modest but positive real growth.

In this context are placed the two alternative Chinese growth regimes discussed earlier: the "growth surge" regime that characterised the decade following China's accession to the WTO and the "transition". The growth surge accompanied a combination of capital and skill accumulation along with productivity improvements brought about by the relocation of vast numbers of rural workers into urban employment in manufacturing and services. Of course, the most significant characteristic of this regime for the rest of the world was its comparatively

\footnotetext{
${ }^{33}$ Of course, this would be readily offset by a modest monetary expansion.
} 
modest growth in consumption and the rise in China's current account surplus. This combination of shocks is constructed from the historical sources described in Tyers (2014) and is represented as the third bundle in Table $5 .{ }^{34}$

The “transition” represents the post-surge pattern of China's growth, which combines slower expansion of capital, skill and productivity, combined with some upward nominal wage pressure associated with the slowdown in rural to urban migration. Most significantly, however, it includes a recovery in consumption growth. ${ }^{35}$ In each case the closures chosen for labour markets and fiscal policy are as indicated in Table 3 and those for monetary policy are listed at the base of Table 5. In the first instance at least, the US, EU and Japan are assumed to be constrained as to monetary expansions by the conventional lower bound. China's monetary policy is enslaved to a US\$ peg in the growth surge regime but it is assumed to be is more expansionary during the transition, targeting the level of employment.

In general, although China has become macro-economically large, the US is still almost twice as large and it has an open and well integrated financial market. Its recovery shocks have substantial real impacts that are strongest at home. Yet it emerges that the Chinese shocks are roughly as strong at home and almost as strong abroad. By comparison, the monetary expansions in the EU and Japan are nominal shocks offsetting deflationary expectations and so have comparatively small impacts both at home and abroad. This can be seen, initially, from the unilateral implementation of these shocks, one region at a time, with the monetary closures also listed in Table 5.

\section{Unilateral shocks}

US recovery: These stimulate US investment, shifting out the global investment demand curve and so tightening global financial markets. With no monetary accommodation in the US these shocks are deflationary there because they raise the supply of goods relative to the stock of money. In the EU and Japan, however, they are inflationary, because higher interest rates release liquidity and because the inflow of finance to the US causes their exchange rates to depreciate against the US\$. In China the effect is deflationary and contractionary because the assumed US\$ peg forces a monetary contraction.

EU Japan monetary expansion shocks: the scale of these depends on the deflationary expectations they are implemented to offset and the sizes indicated in Table 5 are merely

\footnotetext{
34 The construction of the shocks depends importantly on the meta-analysis by Wu (2011).

${ }^{35}$ Again, this cocktail of shocks is as compiled in Tyers (2014).
} 
illustrative. Importantly, the monetary expansions are acting against deflationary expectation shocks, and so the global effects are more modest than otherwise. ${ }^{36}$ Indeed, the international effects of the expansions are not large in scale compared with the effects of the US recovery. They tend to ease international financial markets and, while they yield the intended inflation at home, they cause deflation in the other markets because the lower rates they lead to raise money demand and their exchange rates depreciate with the greater abundance of their currencies. In China, the US\$ peg, combined with the effective appreciation of the US\$, forces a monetary contraction that is deflationary. Overall, the EU-Japan expansion causes a shedding of investable funds from those regions, retarding future growth, but the inflation it causes at home does raise employment and GDP in the short run.

China surge: So far as its international effects are concerned the growth surge is dominated by the surge in excess saving. This causes an excess supply of product to enter global markets and a compressing effect on real global bond yields. ${ }^{37}$ In combination, these are deflationary in the advanced economies, which maintain fixed money supplies in this simulation, primarily because the lower rates soak up liquidity. The excess saving finances increased real investment in all regions but the deflation in the advanced economies contracts employment and real GDP. Substantial real appreciations against China, however, ensure that the purchasing power of home nominal incomes rises in all the advanced regions.

China transition: Here the Chinese government is assumed to discard the US\$ peg and to adopt monetary policy that targets home employment, during what would otherwise be a contractionary transition, notwithstanding continuing growth in productivity, capital and skill. Increased Chinese consumption and decreased excess saving tightens global financial markets. As the source of this change, China's yield rises by more than those in the advance regions. While investment falls in the advanced regions as a consequence, it rises in China because of the more than offsetting effects of the productivity and skill supply shocks (Table 5), that raise China's expected rate of return. The higher yields in the advanced economies release liquidity and are inflationary, raising employment and real GDP. The real purchasing power of income in these regions is mixed in direction, with increases in the EU and Japan but a marginal decline in the US, primarily because the EU and Japan experience larger real appreciations against China.

\footnotetext{
${ }^{36}$ In this comparative static analysis these expectational shocks are not subsequently muted.

${ }^{37}$ The effect on the EU's bond yield is smaller because it has little financial exchange with China, at least as suggested by data on financial flows in 2011.
} 
Collective shocks and the marginal effects of Chinese regimes

Here the US recovery and the EU-Japan monetary expansions are imposed simultaneously with either the Chinese growth surge or the Chinese transition. The results are designed to illustrate the overall effects of the combined shocks but also the change in China's policy regime in the context of other important global macroeconomic changes, thus picking up any interaction effects. To obtain them, the combined shocks to the US, EU, Japan and China are first simulated together, on the presumption that expectations over exchange rates are neutral and that there is no US monetary response. Real exchange rate changes are observed and then injected as further shocks to expectations in a second simulation. This second simulation is conducted with China's growth surge shocks included and then, separately, with China's transition shocks.

The assumption of no US monetary response is retained in the first instance since the period addressed is following the declared cessation of UMP while policy is still constrained by the continuing zero lower bound on short rates. In the case of China, however, a difference between these combined simulations and the separate ones of Table 6 is that China's US\$ peg is assumed to be discarded. This is because the combined shocks otherwise yield an unrealistically large deflation in China. So, in the case of the growth surge, the monetary target is changed to the consumer price level. Producer prices still deflate because the RMB depreciation that occurs drives an expanded wedge between consumer and producer prices. In the case of the China's transition, as in the unilateral results of Table 6, its monetary policy is changed to induce additional stimulus by adopting an employment level target. The whole experiment is then repeated under the assumption that the US adopts a price level targeting monetary policy, at first via continued UMP and, finally, via CMP. The latter case is speculative since it could only arise should short interest rates be lifted in the meantime from the zero lower bound. The results indicate the collective effects of the shocks and their dependence on the Chinese policy regime.

\section{Combined shocks without US monetary response}

The combination of the US recovery, the EU and Japanese monetary expansion and the Chinese growth regimes yields results that are summarised in Table 7. Unsurprisingly, they are similar to the sum of the effects of the separate shocks as listed in Table 6. There is some amplification of these effects, however, due primarily to the added expectation shocks, which embody anticipated real exchange rate changes in expected rates of return and so redirect investment internationally. For the EU and Japan the capital market tightening is larger and yet 
the redirection of real investment from these regions is smaller than in the unilateral case. Their nominal and real depreciations against the US are more modest though their real appreciations against China are enhanced, while their domestic inflations are smaller than in the unilateral case as, therefore, are their real expansions. The real purchasing power of their incomes increases in this combination, though the changes are also modest. In the case of China the real effects of the combination are strongly positive as in the unilateral case, though, under the growth surge, the amplified real depreciation ensures that there is no net gain to the purchasing power of Chinese income.

For the US, the overall effects include gains in real investment compared with the other regions, nominal and real appreciations, including against China, and amplified domestic deflations for both Chinese regimes. Comparatively modest employment gains are still registered and overall gains in real GDP and purchasing power over consumption goods are at levels comparable with the unilateral simulations. The real appreciations against the EU and Japan are smaller when the Chinese policy regime is transitional, though the gains to real GDP and real purchasing power are similar to the unilateral results in Table 6.

Most significant for the US are the domestic deflations. These occur most fundamentally because the US recovery raises the abundance of goods and makes transaction financing money comparatively scarce without accommodating monetary expansions. This is exacerbated in the case of the China growth surge by China's current account surplus, which implies an excess supply of goods. The deflations imply that the combination of shocks such as those implemented here is unlikely to see the US adopting contractionary monetary policy (raising short interest rates above the lower bound) in the near term. It is therefore appropriate to investigate the further implications of the adoption by the US of a price level target that will facilitate monetary expansion.

\section{Combined shocks with US monetary response}

The US monetary target is assumed to be the producer price level. In the first instance the necessary monetary expansion is by further UMP. As shown in Table 8, the US monetary base is required to increase by eight per cent in the China growth surge case and by five per cent in the case of China's transition. The purchases of long bonds by the US Fed that are needed to reverse the tightening effect on global financial markets evident in Table 7. This illustrates the pivotal role of US monetary policy in short run macro-economic behaviour at the global level. In the context of the other shocks, it enhances expansions in employment and real GDP in all four regions. 
Were the model applied to simulate a simple unilateral monetary expansion by the US on its own, it would yield a "beggar thy neighbour" result, with real gains in the US coinciding with contractions elsewhere. In this case the gains are more widespread because of the price level targeting policies adopted in the EU and Japan, as well as in China. Without these price level targets, a US monetary expansion would be deflationary, and therefore contractionary, elsewhere because it appreciates exchange rates relative to the US. In this instance, the monetary expansion in the US induces expansions in all regions. The producer price deflation in the US is eliminated and that in China is substantially reduced. More savings are generated globally and so the gains in real investment in the US and China both increase, while the investment contractions in the EU and Japan are smaller.

A final simulation examines the effects of the equivalent US monetary response should it be possible for this to be undertaken via conventional monetary policy (CMP). As indicated earlier, this is speculative since a period of tightening at the short end is required before CMP can be effective. The results are summarised in Table 9. They show less downward pressure on real yields in the long bond markets represented in the model, leaving some net tightening in China. More investment is therefore attracted to the US relative to China. Overall, however, the aggregate real effects are similar irrespective of the type of US monetary expansion undertaken.

\section{The marginal effects of the change in Chinese regime}

The differences between the results for the Chinese growth surge and its transition, drawn from Tables 7 through 9, are summarised in Table 10 and compared with the unilateral results of Table 6. These differences indicate that, while China's global impacts are smaller than those of the US, they are nonetheless substantial, and, for the reasons discussed above, they are proportionally amplified by any US monetary expansion. The central element of the change of Chinese regime is the decline in excess saving. This tightens the Chinese financial market but, because less Chinese saving emerges into global markets it also causes tightening abroad, particularly within China's most intensive financial partnership, that with the US.

The financial tightening due to China's regime change is amplified, first, by anticipation of the US real appreciation, and this occurs in the absence of any US monetary policy response. But US monetary expansions that target its producer price level tend to enhance the softening effect of China's growth surge driven excess saving supply. This raises the contrast between the two Chinese regimes, in terms of their effects on real interest rates and the monetary expansions needed in the US, EU and Japan to maintain their targets. It also amplifies the impact of the 
change in regime over the global distribution of investment. The switch to China's transition reduces real investment everywhere but by most when the global economy is inflated by concatenating monetary expansions that are triggered by that in the US.

Notwithstanding these effects on financial markets, and the significant growth effects of declines in real investment in both China and the US, the impacts of the change in Chinese regime on current real GDP and income levels in the other advanced economies remain modest.

\section{Conclusion}

Given the relatively recent attainment by China of global macroeconomic significance, its still more recent transition from the East Asian model of export driven growth suggests important consequences for the global economy. While recent global change has been commonly seen as driven in one way or another by the emergence of China, it is important to recognise that its economy is still smaller than that of either the US or Europe and its financial market is less open than theirs. Indeed, major changes are occurring in the US, Europe and Japan that are likely to have larger global implications. The research presented here focusses on the impacts of the change in China's growth regime in the context of shocks emerging from the other large economic regions.

An elemental global macro model is introduced that emphasises global financial integration and accounts for the roles of UMP in the advanced economies. It is first applied to the old controversy over the sources of China's growth. When that growth is productivity driven, the results indicate that the US gains employment in the short run, though it loses real investment. On the other hand, when China's growth is driven by capital accumulation the US loses employment in the short run, but gains real investment. These conclusions cut against the simple logic that follows the flow of investment but ignores monetary and exchange rate effects. But they tie together the early assertions that China's growth was capital driven and that it caused labour displacement in the US and other advanced regions.

The model is then applied to examine the shift from China's growth surge regime to its current "transition" in the context of other important global shocks, which include the US real recovery and substantial monetary expansions in the EU and Japan. These shocks are simulated individually and collectively, so interactions are readily observed. The strongest mode of interaction proves to be via monetary policy. When all the large economies adopt price level 
targets, an expansion by one necessitates expansion by the others as well. The simultaneous introduction of all the shocks tends, then, to amplify nominal effects.

The real expansion shocks in the US and China, combined with the changes in China's implied saving rate prove to have the largest impacts, both domestically and internationally. If monetary policy in the advanced regions were static these real shocks would be deflationary, most fundamentally because they raise the relative abundance of goods and make transaction financing money comparatively scarce. These simulated deflations imply that the combination of shocks implemented here is unlikely to see the US adopting contractionary monetary policy (raising short interest rates above the lower bound) in the near term. Further monetary expansion by the US is therefore considered.

The global financial tightening due to China’s shift from a high saving to a lower saving, transitional regime is amplified, first, by anticipation of the US real appreciation, and second by concatenating monetary expansions triggered by action against deflation in the US. This raises the contrast between the two Chinese regimes, in terms of their effects on real interest rates and the monetary expansions needed in the US, EU and Japan to maintain their targets. It also amplifies the impact of the change in regime over the global distribution of real investment. The switch to China's transition reduces real investment everywhere but by most when the global economy is inflated by monetary expansions. Notwithstanding these effects on financial markets, and the significant growth effects of declines in real investment that are strongest in China and the US, the simulated impacts of the change in Chinese regime on current real GDP and income levels in the other advanced economies are modest.

\section{References}

Aghion, P., U. Akcigit and P. Howitt (2013), "What do we learn from Schumpeterian growth theory?” in P. Aghion and S. Durlauf, Handbook of Economic Growth, Volume II, North-Holland: Elsevier.

Aghion P, M. Dewatripont, L. Du, A. Harrison A and P. Legros (2014), “Industrial policy and competition”, forthcoming in the American Economic Journal.

Arora, V., R. Tyers and Y. Zhang (2014), "Reconstructing the savings glut: the global implications of Asian excess saving”, CAMA Working Paper No. 2014-02/20, Centre for Applied Macroeconomics, Australian National University, Canberra, February.

Athukorala, P. (2011), "Production Networks and Trade Patterns in East Asia: Regionalization or Globalization?" Asian Economic Papers, MIT Press, 10(1): 65-95, January.

Autor, D.H., D. Dorn and G.H.Hanson (2013), “The China syndrome: local labor market effects of competition in the United States”, American Economic Review, forthcoming. 
Beltran, D.O., M. Kretchmer, J. Marquez and C.P. Thomas (2012), “Foreign holdings of US Treasuries and US Treasury yields”, Federal Reserve System International Finance Discussion Paper No. 1041, Washington DC, January.

Bergsten, C.F., C. Freeman, N.R. Lardy and D.J. Mitchell (2008), China's Rise: Challenges and Opportunities, Washington DC: Peterson Institute for International Economics.

Berman, E., J. Bound and Z. Griliches (1994), “Changes in the demand for skilled labour within US manufacturing: evidence from the annual survey of manufactures", Quarterly Journal of Economics, 109(2): 367-397.

Bernanke, B.S. (2005), “Remarks by the Governor”, Sandridge Lecture, Virginia Association of Economists, Richmond Virginia, March, Federal Reserve Board.

(2011), "Global imbalances: links to economic and financial stability”, speech given at the Banque de France Financial Stability Review Launch Event, Paris, France February 18.

Blanchard. O. and F. Giavazzi (2006), "Rebalancing growth in China: a three-handed approach," China and the World Economy, Institute of World Economics and Politics, Chinese Academy of Social Sciences, 14(4): 1-20.

Bound, J. and G. Johnson (1992), "Changes in the structure of wages in the 1980s: an evaluation of alternative explanations”, American Economic Review, 82(3): 371-392.

Borio, C. and P. Disyatat (2011), “Global imbalances and the financial crisis: link or no link”, BIS Working Paper 346, Basel, May.

Chen, Q., A. Filardo, D. He, F. Zhu (2014), "Financial crisis, unconventional monetary policy and international spillovers”, presentation at the ECB-IMF Conference on International Dimensions of Conventional and Unconventional Monetary Policy Frankfurt, April 2930.

Chinn, M.D., B. Eichengreen and H. Ito (2012), "Rebalancing global growth”, in O. Canuto and D. Leipziger (eds), Ascent after Descent: Regrowing Economic Growth after the Great Recession, Washington DC: World Bank: 35-86.

Chinn, M.D. and H. Ito (2007), "Current account balances, financial development and institutions: assaying the world 'saving glut'”, Journal of International Money and Finance, 26: 546-569.

Choi, H., N.C. Mark and D. Sul (2008), "Endogenous discounting, the world saving glut and the US current account”, Journal of International Economics, 75: 30-53.

di Giovanni, J., A.A. Levchenko and J. Zhang (2013), “Global welfare effect of China: trade

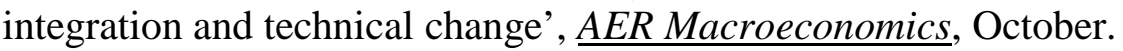

Eichengreen, B. (2004), "Global Imbalances and the Lessons of Bretton Woods," NBER, Working Paper 10497, Cambridge Mass: National Bureau of Economic Research.

Eickmeier, S. and M. Kuehnlenz (2013), “China’s role in global inflation dynamics”, Discussion Paper 7-2013, Deutsche Bundesbank.

Feldstein, M. and C.Y. Horioka (1980), "Domestic Saving and International Capital Flows," Economic Journal, Royal Economic Society, 90(358): 314-29, June.

Garner, J. and H. Qiao (2013), “China - household consumption most likely US1.6 trillion larger than officially stated”, Asian Insight, Morgan Stanley Research, 28 February 2013, http://www.morganstanleychina.com/views/121217.html. 
Genberg, H. and W. Zhang (2010), “Can China save the world by consuming more?” VOX EU, 25 April.

Harris, R.G. and P.E. Robertson (2013), “Trade, wages and skill accumulation in the emerging giants”, Journal of International Economics, 89(2): 407-421, March.

Harris, R.G, P.E. Robertson and J. Xu (2011), “The international effects of China's trade and education booms”, The World Economy, 34(10): 1703-1725.

Haskel, J., R.Z. Lawrence, E.E. Leamer and M.J. Slaughter (2012), "Globalization and U.S. Wages: Modifying Classic Theory to Explain Recent Facts," Journal of Economic Perspectives, American Economic Association, 26(2): 119-40, Spring.

He, D. and R.N. McCauley (2013), “Transmitting global liquidity to East Asia: policy rates, bond yields, currencies and dollar credit”, Hong Kong Institute for Monetary Research Working Paper No.15/2013, BIS Working Papers 431, Bank for International Settlements, October.

He, D., L. Cheung, W. Zhang and T. Wu (2012), "How would capital account liberalization affect China's capital flows and renminbi real exchange rates?" China and the World Economy, 20(6): 29-54, November.

Helpman, E., O. Itskhoki and S.J. Redding (2010), "Inequality and Unemployment in a Global Economy,” Econometrica, 78(4): 1239-83.

Hsieh, C.T. and P. Klenow (2009), "Misallocation and manufacturing TFP in China and India", Quarterly Journal of Economics, 124: 1403-1448, November.

Huang, Y., J. Chang and L. Yang (2012), “Consumption recovery and economic rebalancing in China”, prepared for the Asian Economic Panel, March 22-23, Seoul, Korea, published in Asian Economic Papers, 12(1): 47-67, Winter/Spring 2013.

Ito, H. (2009), "US current account debate with Japan then, and China now”, Journal of Asian Economics, 20: 294-313.

(2013), "Monetary policy in Asia and the Pacific in the post, post-crisis era”, presented at the 36th Pacific Trade and Development (PAFTAD) Conference, "Financial Development and Cooperation in Asia and the Pacific,” Hong Kong Monetary Authority, November 19-21, 2013.

Johnson, R.S., R.A. Zuber and J.M. Gandar (2010), “A re-examination of the market segmentation theory as a pedagogical model”, Journal of Financial Education, 36(1/2): 1-37, Spring/Summer.

Krugman, P. (1994), “The myth of Asia’s miracle”, Foreign Affairs, 73(6): 62-78, Nov-Dec. (2010) “Capital export, elasticity pessimism and the renminbi (wonkish)” New York Times (blog), 16 March.

Kuijs, L. (2006), “How will China’s saving-investment balance evolve?” World Bank Policy Research Working Paper 3958, Beijing, July.

Lardy, N.R. (2006), 'Toward a consumption-driven growth path” Policy Brief 06-6, Washington DC: Peterson Institute for International Economics.

Lardy, N.R. (2012), Sustaining China's Growth after the Global Financial Crisis, Washington DC: Peterson Institute for International Economics, January. 
Leamer, E.E (1996), "Wage inequality from international competition and technological change: theory and country experience," American Economic Review, American Economic Association, 86(2): 309-14, May.

Ma, G. and W. Yi (2010), “China’s high saving rate: myth and reality”, International Economics, 122: 5-40.

McKibbin, W.J. and A.B. Stoeckel (2012), 'Global Fiscal Consolidation', Asian Economic Papers, 11(1): 124-146, February.

McKinnon, R. (2013), “The U.S. saving deficiency, current-account deficits, and deindustrialization: Implications for China”, Journal of Policy Modeling, 35(3): 449458, May-June.

Rey, H. (2013), "Dilemma not trilemma: the global financial cycle and monetary policy independence”, Federal Reserve Bank of Kansas City Economic Symposium at Jackson Hole, August.

Rodrik, D. (2005), "Growth strategies," in: P. Aghion and S. Durlauf (eds.), Handbook of Economic Growth, first edition, vol 1, chapter 14: 967-1014, Elsevier.

Rodrik, D. (2010), "Making room for China in the world economy," American Economic Review, 100(2): 89-93, May.

Rogoff, K. (2013), “Inflation is still the lesser evil”, Project Syndicate, 6 June 2013, http://www.project-syndicate.org/commentary/, accessed 12 June 2013.

Shiller, R. J., J.Y. Campbell and K.L. Schoenholtz (1983), "Forward rates and future policy: interpreting the term structure of interest rates", Brookings Papers on Economic Activity, 1983(1): 173-223.

Shin, H.S. (2011), “Global Banking Glut and Loan Risk Premium”, Presented at the 12th Jacques Polak Annual Research Conference Hosted by the International Monetary Fund, Washington, DC, November 10-11.

Song, L., J. Yang and Y Zhang (2011), “State-owned enterprises’ outward investment and the structural reform in China”, China and the World Economy, 19(4): 38-53.

Schweinberger, A. (2013), “The euro crisis: budget deficit reduction, international policy interactions and growth”, University of Konstanz and Zeppelin University, Germany, February, not published since the author is sadly deceased.

Tyers, R. (2014), “Looking inward for transformative growth”, China Economic Review, 29: 166-184.

(2015a), "Pessimism shocks in a model of global macroeconomic interdependence", International Journal of Economics and Finance, 7(1): 37-59, January.

(2015b), "International effects of China's rise and transition: neoclassical and Keynesian perspectives”, Journal of Asian Economics, 37: 1-19, April.

(2015c), “Financial integration and China’s global impact”, CAMA Working Papers, Australian National University, January.

Tyers, R. and Y. Yang (1997), "Trade with Asia and skill upgrading: effects on labor markets in the older industrial countries", Review of World Economics, 133(3): 383-418, September.

(2000). "Capital-Skill Complementarity and Wage Outcomes Following Technical Change in a Global Model”, Oxford Review of Economic Policy, 16: 23-41. 
Tyers, R. and Y. Zhang (2011), “Appreciating the renminbi”, The World Economy, 34(2): 265297, February.

(2014), "Real exchange rate determination and the China puzzle", Asian-Pacific Economic Literature, 28(2): 1-32, November.

Tyers, R., Y. Zhang and T.S. Cheong (2013), “China’s saving and global economic performance”, Chapter 6 in Garnaut, R., F. Cai and L. Song (eds,) China: A New Model for Growth and Development, Canberra: ANU E Press and Beijing: Social Sciences Academic Press, Pp 97-124.

Wicksell, K. (1898), Interest and prices: a study of the causes regulating the value of money, Translation from German, London: Macmillan, 1936.

Winchester, N. and D. Greenaway (2007), "Rising wage inequality and capital-skill complementarity," Journal of Policy Modeling, 29(1): 41-54.

World Bank (2013), Capital for the Future: Saving and Investment in an Interdependent World, Washington DC, 147 pp.

Wu,Y. (2011), “Total factor productivity growth in China: a review”, Journal of Chinese Economic and Business Studies, 9(2): 111-126.

Yang, D.T. (2012), “Aggregate savings and external imbalances in China”, Journal of Economic Perspectives, 26, 4, 125-146. 
Figure 1: China's Saving Surplus, \% GDP

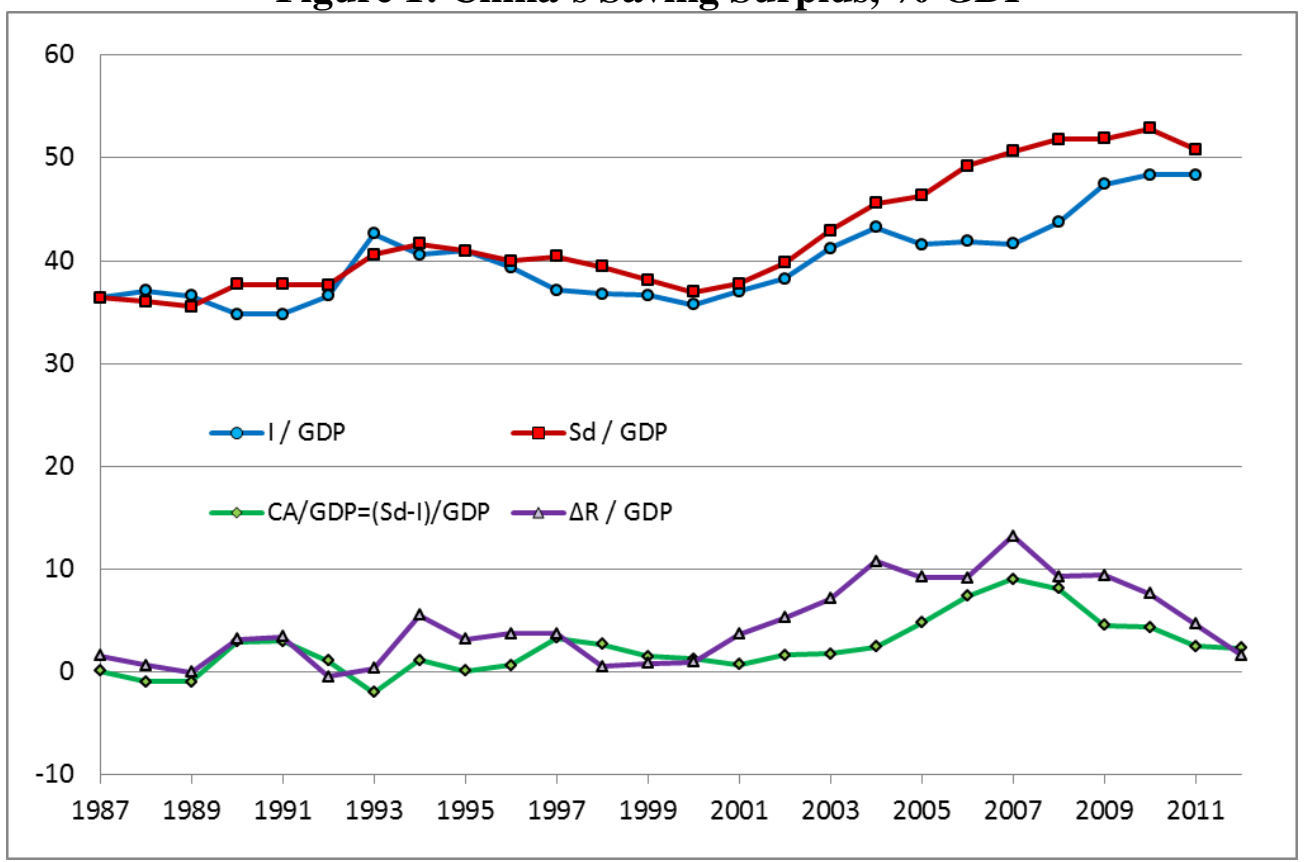

Sources: National Bureau of Statistics yearbook 2009-2012; IMF IFS data base. The value for the current account in 2012 is based on the trade balance and the authors' estimate of net factor income from abroad in that year. 
Figure 2: US, European and Japanese Government Bond Yields Since 2000

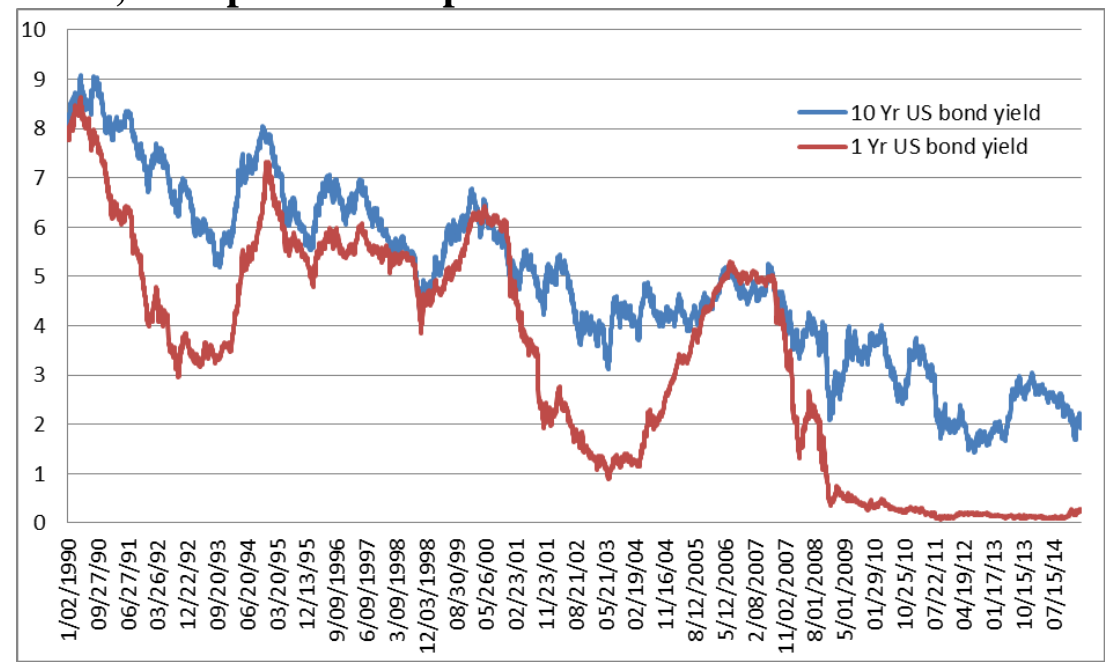

Source: US Treasury.

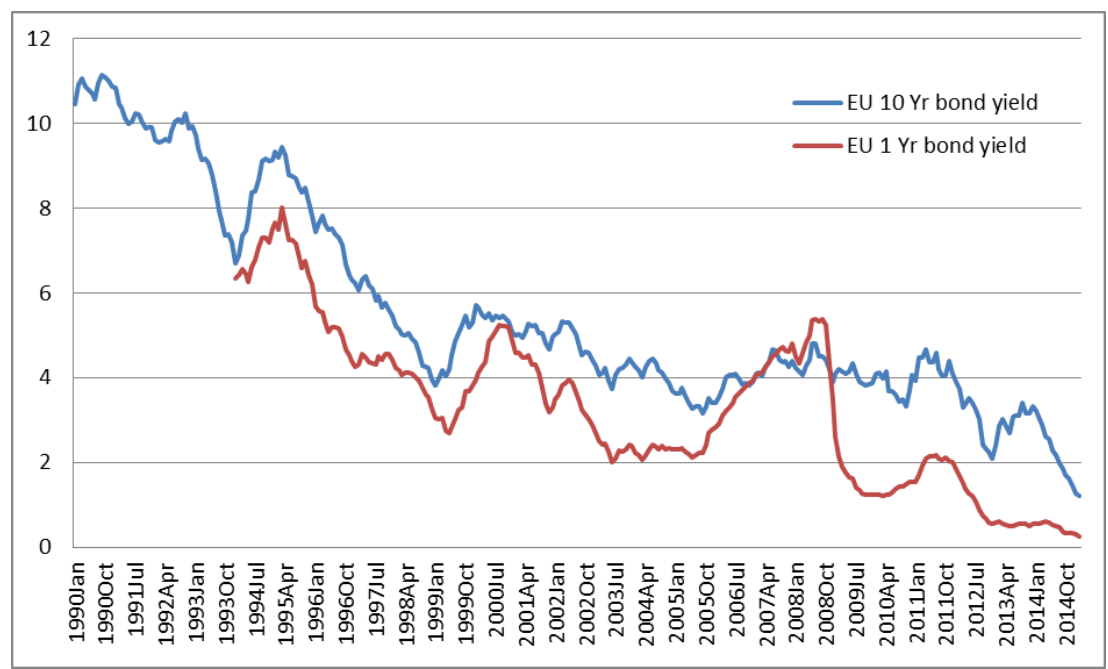

Source: European Central Bank.

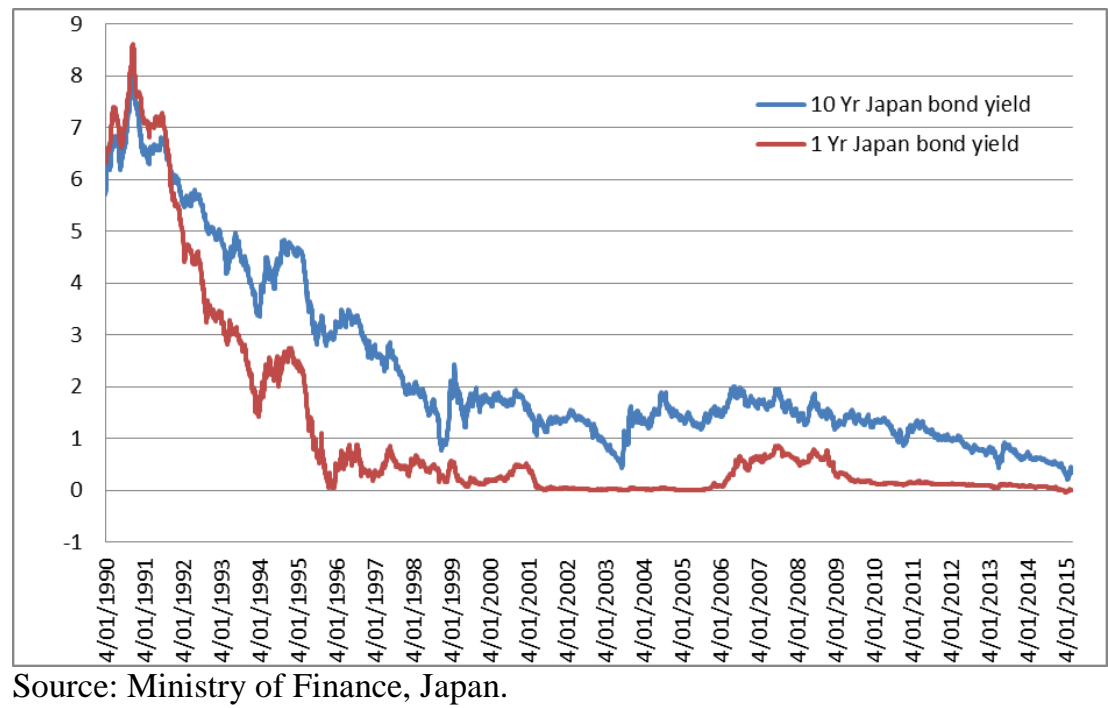


Table 1: Relative Economic Sizes of China and the Other Large Regions, ca 2011:

\begin{tabular}{lllll}
\hline \multicolumn{1}{c}{ \% of world } & China & US & EU(26) & Japan \\
\hline GDP & 11 & 22 & 26 & 9 \\
Consumption, $C$ & 8 & 27 & 26 & 9 \\
Investment, $I$ & 20 & 15 & 22 & 8 \\
Government spending, $G$ & 7 & 20 & 30 & 10 \\
Exports, $X$ & 17 & 17 & 25 & 7 \\
Imports, $M$ & 15 & 21 & 23 & 8 \\
Total domestic saving, $S^{D}$ & 19 & 13 & 20 & 9 \\
\hline
\end{tabular}

Sources: National accounts data supply most of the elements though adjustments have been required to ensure that current accounts sum to zero globally, as do capital/financial accounts. The IMF-IFS database is the major source but there is frequent resort to national statistical databases.

Table 2: Shares of Total Domestic Saving Directed to Investment in Each Region, 2011

\begin{tabular}{lcccccc}
\hline $\begin{array}{l}\text { \% of row total } \\
\text { saving }\end{array}$ & US & EU(26) & Japan & China & Australia & RoW \\
\hline US $^{\mathrm{b}}$ & 68.0 & 13.3 & 6.4 & 6.4 & 1.5 & 4.4 \\
EU(26) $^{\mathrm{c}}$ & 12.9 & 80.1 & 2.3 & 2.3 & 0.9 & 1.5 \\
Japan $^{\mathrm{d}}$ & 14.0 & 3.3 & 72.2 & 6.2 & 0.7 & 3.6 \\
China $^{\mathrm{c}}$ & 9.2 & 0.6 & 0.9 & 81.1 & 0.1 & 8.0 \\
Australia $^{\mathrm{e}}$ & 13.0 & 4.8 & 2.3 & 2.1 & 77.3 & 0.4 \\
Rest of world & 3.4 & 3.9 & 2.6 & 2.8 & 0.1 & 87.2 \\
\hline
\end{tabular}

a These shares sum to 100 horizontally. They are based on 2011 investment flows. The original flow matrix is inconsistent with data on saving and investment from national accounts and so a RAS algorithm is used to ensure that row and column sums are consistent with other data. The row sums of the original flow matrix are total saving by region and the column sums are total investment by region. These sums are sourced from the IMF-IFS database and the World Bank database.

b USA: values are based on official statistics, BEA.

c EU and China: indirect information from USA, Australian and Japanese statistics.

d Japan: estimated based on FDI data, assuming investment outflow=FDI*1.6. The ratio 1.6 is that of USA reported inward investment from Japan divided by Japanese reported outward FDI to the USA.

e Australia: Australian Bureau of Statistics "International Investment Position, Australia: Supplementary Statistics, 2011".

$\mathrm{f} \mathrm{RoW}$ is a residual. Its saving is inferred from national accounts estimates and its investment abroad is determined to balance the matrix of financial flows.

Sources: As per the notes above. 
Table 3: Simulation Closures ${ }^{\mathrm{a}}$

\begin{tabular}{ll}
\hline Closure & \\
\hline Labour market: & $\begin{array}{l}\text { Exogenous nominal production (unskilled) wage with } \\
\text { endogenous production employment }\end{array}$ \\
Fiscal policy: & $\begin{array}{l}\text { Exogenous nominal government spending and endogenous } \\
\text { government revenue at fixed rates of tax on income, consumption } \\
\text { and trade }\end{array}$ \\
& 1. Monetary base ${ }^{\mathrm{d}}, M^{B}$ \\
Monetary policy targets $^{b}$ & 2. Producer price level, $P^{P}$ \\
& 3. Consumer price level, $P^{C}$ \\
& 4. Production employment, $L$ \\
\hline
\end{tabular}

a Since the model is a system of non-linear simultaneous equations and more variables are specified than equations in the system, there is flexibility as to the choice of those to make exogenous. This choice mirrors assumptions about the behaviour of labour markets, fiscal deficits and monetary policy targets.

b Money supplies can be set to target any of the three price levels (consumer, producer and GDP), nominal exchange rates against the US\$ or nominal GDP levels.

c Australia is a small region also identified in the model. Its monetary policy targets the producer price level, which ensures no change in employment.

$\mathrm{d}$ No changes in commercial bank reserve behaviour are assumed so that money multipliers remain constant. 
Table 4: Global Effects of the Chinese Productivity and Capital Shocks ${ }^{\mathrm{a}}$

\begin{tabular}{|c|c|c|c|c|c|}
\hline \% changes & Regional shocks & US & $\mathrm{EU}(26)$ & Japan & China \\
\hline \multicolumn{6}{|l|}{ Real bond yield, $r$} \\
\hline & $5 \%$ productivity & 0.27 & 0.28 & 0.27 & 0.70 \\
\hline & $5 \%$ capital stock & -0.06 & 0.04 & -0.08 & -1.04 \\
\hline \multicolumn{6}{|c|}{ Consumer price level, $P^{C}$} \\
\hline & $5 \%$ productivity & 0.10 & -0.16 & -0.04 & -2.84 \\
\hline & $5 \%$ capital stock & -0.31 & -0.54 & -0.23 & -0.10 \\
\hline \multicolumn{6}{|c|}{ Producer price level, $P^{P}$} \\
\hline & $5 \%$ productivity & 0.14 & 0.10 & 0.13 & -4.68 \\
\hline & $5 \%$ capital stock & -0.07 & -0.11 & -0.05 & -2.84 \\
\hline \multicolumn{6}{|c|}{ Exchange rate vs US\$, E } \\
\hline & $5 \%$ productivity & $0.00^{b}$ & 0.28 & 0.34 & 2.94 \\
\hline & $5 \%$ capital stock & $0.00^{b}$ & 0.02 & -0.25 & -0.68 \\
\hline \multicolumn{6}{|c|}{ Real exchange rate vs US, $e_{R}$} \\
\hline & $5 \%$ productivity & $0.00^{b}$ & 0.30 & 0.35 & -1.73 \\
\hline & $5 \%$ capital stock & $0.00^{b}$ & 0.09 & -0.26 & -3.48 \\
\hline \multicolumn{6}{|l|}{ Real investment, $I / P^{P}$} \\
\hline & $5 \%$ productivity & -0.23 & -0.21 & -0.22 & 4.68 \\
\hline & $5 \%$ capital stock & 0.04 & -0.01 & 0.02 & -1.71 \\
\hline \multicolumn{6}{|c|}{ Production employment, $L$} \\
\hline & $5 \%$ productivity & 0.18 & 0.12 & 0.16 & 0.12 \\
\hline & $5 \%$ capital stock & -0.09 & -0.13 & -0.06 & -0.60 \\
\hline \multicolumn{6}{|c|}{ Real output (GDP), $Y / P^{Y}$} \\
\hline & $5 \%$ productivity & 0.03 & 0.02 & 0.03 & 5.03 \\
\hline & $5 \%$ capital stock & -0.02 & -0.02 & -0.01 & 2.31 \\
\hline \multicolumn{6}{|l|}{ Real income $Y / P^{C}$} \\
\hline & $5 \%$ productivity & 0.06 & 0.32 & 0.20 & 3.34 \\
\hline & $5 \%$ capital stock & 0.28 & 0.56 & 0.18 & -0.51 \\
\hline
\end{tabular}

a These results are from the model described in the text with the closures as for Table 3, except that the monetary target is the monetary base and so there is no monetary policy response in any region. The shocks are simple increases in total factor productivity on the one hand and the capital stock on the other. "Moderate" financial integration parameters are used, which are values of the elasticity of substitution between assets for each region, $\sigma_{i}^{I}$ : US: 20, EU: 20, Japan: 15, China: 10, Australia: 20, Rest of World: 10. Note also that the GDP price level, $P^{Y}$, is left out, for economy of space and because its value changes in these simulations are similar to those of the producer price level, $P^{P}$.

b Nominal and real exchange rates are defined relative to the US\$.

Source: Simulations of the model described in the text. 
Table 5: Regional Shocks and Monetary Closures $^{\mathrm{a}, \mathrm{b}}$

\begin{tabular}{clr}
\hline Scenario & Shocks, \% & \\
\hline 1. US recovery & & 3 \\
& Productivity, $A^{Y}$ & -3 \\
& Relative physical capital cost, $\gamma$ & \\
& Monetary target is initially $M_{B}$ & \\
& QE share of any $M^{B}$ expansion, $s^{Q E}$ & -80 \\
& & \\
2. Europe and Japan & & 400 \\
expansions & QE share of EU $M_{B}$ expansion, $s^{Q E}$ & -3 \\
& Expected EU inflation, $\pi^{e}$ & -3 \\
& Expected Japanese inflation, $\pi^{e}$ & 2 \\
& EU monetary target, $P^{C}$ & 2 \\
& Japanese monetary target, $P^{C}$ &
\end{tabular}

3. China growth surge

Productivity, $A^{Y} \quad 3$

Consumption constant, $A^{C} \quad-10$

Capital stock, $K$

Skill stock, $S \quad 10$

Monetary target is US\$ peg, $E$

\section{China transition}

$\begin{array}{lr}\text { Productivity, } A^{Y} & 1 \\ \text { Consumption constant, } A^{C} & 15 \\ \text { Capital stock, } K & 3 \\ \text { Skill stock, } S & 10 \\ \text { Nominal wage }^{c}, W & 4 \\ \text { Monetary target is employment, } L & \end{array}$

\footnotetext{
a All shocks are undertaken assuming the labour market and fiscal closures indicated in Table 3. Monetary targets differ across regions as indicated at the base of the table.

b Regions not discussed are Australia, which maintains a producer price level target and the Rest of the World, which maintains a US\$ peg.

c The Chinese nominal wage is shocked in the transition case only to allow for accelerated relative production wage growth, designed to foster consumption.
} 
Table 6: Effects of the US, EU-Japan and China Shocks, each in Isolation ${ }^{\text {a }}$

\begin{tabular}{|c|c|c|c|c|c|}
\hline \% changes & Regional shocks & US & $\mathrm{EU}(26)$ & Japan & China \\
\hline \multicolumn{6}{|l|}{ Real bond yield, $r$} \\
\hline & US recovery & 2.57 & 1.14 & 1.53 & 2.71 \\
\hline & EU-Japan easing & -0.05 & -0.32 & -0.41 & 0.07 \\
\hline & China growth surge & -0.36 & -0.02 & -0.34 & -3.12 \\
\hline & China transition & 0.59 & 0.52 & 0.55 & 2.09 \\
\hline \multicolumn{6}{|c|}{ Consumer price level, $P^{C}$} \\
\hline & US recovery & -2.29 & 2.61 & 1.64 & -2.89 \\
\hline & EU-Japan easing & -0.25 & $2.00^{\mathrm{b}}$ & $2.00^{\mathrm{b}}$ & -0.53 \\
\hline & China growth surge & -1.00 & -1.34 & -0.54 & -2.31 \\
\hline & China transition & 0.41 & -0.20 & -0.11 & 1.45 \\
\hline \multicolumn{6}{|c|}{ Producer price level, $P^{P}$} \\
\hline & US recovery & -1.92 & 1.17 & 0.84 & -2.19 \\
\hline & EU-Japan easing & -0.06 & 1.35 & 1.55 & -0.13 \\
\hline & China growth surge & -0.32 & -0.33 & -0.19 & -7.82 \\
\hline & China transition & 0.35 & 0.21 & 0.26 & -0.79 \\
\hline \multicolumn{6}{|l|}{ Monetary base, $M_{B}$} \\
\hline & US recovery & $0.00^{\mathrm{b}}$ & $0.00^{\mathrm{b}}$ & $0.00^{\mathrm{b}}$ & -4.26 \\
\hline & EU-Japan easing & $0.00^{\mathrm{b}}$ & 2.07 & 2.16 & -0.16 \\
\hline & China growth surge & $0.00^{\mathrm{b}}$ & $0.00^{\mathrm{b}}$ & $0.00^{\mathrm{b}}$ & 0.40 \\
\hline & China transition & $0.00^{\mathrm{b}}$ & $0.00^{\mathrm{b}}$ & $0.00^{\mathrm{b}}$ & 4.40 \\
\hline \multicolumn{6}{|c|}{ Exchange rate vs US\$, E } \\
\hline & US recovery & $0.00^{\mathrm{d}}$ & -5.68 & -5.84 & $0.00^{\mathrm{c}}$ \\
\hline & EU-Japan easing & $0.00^{\mathrm{d}}$ & -2.65 & -3.25 & $0.00^{\mathrm{c}}$ \\
\hline & China growth surge & $0.00^{\mathrm{d}}$ & -0.30 & -1.24 & $0.00^{\mathrm{c}}$ \\
\hline & China transition & $0.00^{\mathrm{d}}$ & 0.80 & 1.35 & -0.88 \\
\hline \multicolumn{6}{|c|}{ Real exchange rate vs US, $e_{R}$} \\
\hline & US recovery & $0.00^{\mathrm{d}}$ & -3.67 & -3.54 & -0.23 \\
\hline & EU-Japan easing & $0.00^{\mathrm{d}}$ & -1.08 & -1.70 & -0.05 \\
\hline & China growth surge & $0.00^{\mathrm{d}}$ & -0.09 & -1.26 & -8.64 \\
\hline & China transition & $0.00^{\mathrm{d}}$ & 0.79 & 1.34 & -0.37 \\
\hline \multicolumn{6}{|l|}{ Real investment, $I / P^{P}$} \\
\hline & US recovery & 5.79 & -2.89 & -2.62 & -2.02 \\
\hline & EU-Japan easing & 0.10 & -1.48 & -2.78 & 0.02 \\
\hline & China growth surge & 0.29 & 0.04 & 0.15 & 2.96 \\
\hline & China transition & -0.86 & -0.59 & -0.67 & 3.23 \\
\hline \multicolumn{6}{|c|}{ Production employment, $L$} \\
\hline & US recovery & 1.24 & 1.43 & 1.02 & -2.97 \\
\hline & EU-Japan easing & -0.08 & 1.65 & 1.89 & -0.17 \\
\hline & China growth surge & -0.38 & -0.40 & -0.24 & 1.25 \\
\hline & China transition & 0.42 & 0.25 & 0.32 & $0.00^{\mathrm{c}}$ \\
\hline \multicolumn{6}{|c|}{ Real output (GDP), $Y / P^{Y}$} \\
\hline & US recovery & 3.23 & 0.25 & 0.18 & -0.80 \\
\hline & EU-Japan easing & -0.01 & 0.29 & 0.33 & -0.05 \\
\hline & China growth surge & -0.07 & -0.07 & -0.04 & 10.40 \\
\hline & China transition & 0.07 & 0.04 & 0.06 & 4.83 \\
\hline \multicolumn{6}{|l|}{ Real income $Y / P^{C}$} \\
\hline & US recovery & 3.90 & -1.88 & -0.71 & 0.23 \\
\hline & EU-Japan easing & 0.22 & -0.12 & -0.08 & 0.42 \\
\hline & China growth surge & 0.79 & 1.35 & 0.34 & 2.04 \\
\hline & China transition & -0.05 & 0.51 & 0.44 & 4.15 \\
\hline
\end{tabular}


a These results are from the model described in the text with the closures and shocks listed in Tables 3 and 5 . The "moderate" financial integration parameters referred to are values of the elasticity of substitution between assets for each region, $\sigma_{i}^{I}$ : US: 20, EU: 20, Japan: 15, China: 10, Australia: 20, Rest of World: 10.

b Here the US monetary base is held fixed on the presumption that UMP has ceased and CMP continues to be constrained by the zero lower bound. The EU and Japan also hold fixed money supplies except where their expansion shock is considered, in which case they target their consumer price levels, raising them by two percentage points.

c China’s monetary policy is assumed to target the US\$ peg in the case of a continued growth surge (a continuation of the pre-GFC exchange rate targeting regime). In the case of the less expansionary transition, it is assumed that the target is to retain the original level of employment. This avoids what would otherwise be a contraction in Chinese labour demand.

$\mathrm{d}$ Real and nominal exchange rates are defined relative to the US.

Source: Simulations of the model described in the text. 
Table 7: Effects of the Shocks in Combination, with no US Monetary Response ${ }^{\text {a,b }}$

\begin{tabular}{|c|c|c|c|c|c|}
\hline \% changes & Chinese shocks & US & EU(26) & Japan & China \\
\hline \multicolumn{6}{|l|}{ Real bond yield, $r$} \\
\hline & China growth surge & 1.05 & 1.62 & 1.87 & -0.66 \\
\hline & China transition & 2.30 & 2.85 & 3.24 & 4.83 \\
\hline \multicolumn{6}{|c|}{ Consumer price level, $P^{C}$} \\
\hline & China growth surge & -3.89 & $2.00^{c}$ & $2.00^{c}$ & $0.00^{d}$ \\
\hline & China transition & -2.15 & $2.00^{c}$ & $2.00^{c}$ & 3.07 \\
\hline \multicolumn{6}{|c|}{ Producer price level, $P^{P}$} \\
\hline & China growth surge & -2.86 & 1.93 & 1.70 & -7.79 \\
\hline & China transition & -2.03 & 1.80 & 1.90 & -0.79 \\
\hline \multicolumn{6}{|l|}{ Monetary base, $M_{B}$} \\
\hline & China growth surge & $0.00^{c}$ & 1.59 & 0.95 & 0.30 \\
\hline & China transition & $0.00^{c}$ & 0.63 & 0.36 & 2.49 \\
\hline \multicolumn{6}{|c|}{ Exchange rate vs US\$, E } \\
\hline & China growth surge & $0.00^{\mathrm{e}}$ & -7.14 & -8.22 & -5.77 \\
\hline & China transition & $0.00^{\mathrm{e}}$ & -4.26 & -4.49 & -5.29 \\
\hline \multicolumn{6}{|c|}{ Real exchange rate, $e_{R}$} \\
\hline & China growth surge & $0.00^{\mathrm{e}}$ & -2.88 & -4.41 & -12.22 \\
\hline & China transition & $0.00^{\mathrm{e}}$ & -0.58 & -0.88 & -3.03 \\
\hline \multicolumn{6}{|l|}{ Real investment, $I / P^{P}$} \\
\hline & China growth surge & 5.10 & -2.16 & -2.76 & 0.18 \\
\hline & China transition & 4.00 & -2.71 & -3.17 & -1.06 \\
\hline \multicolumn{6}{|c|}{ Production employment, $L$} \\
\hline & China growth surge & 0.06 & 2.35 & 2.07 & 1.29 \\
\hline & China transition & 1.11 & 2.19 & 2.32 & $0.00^{d}$ \\
\hline \multicolumn{6}{|c|}{ Real output (GDP), $Y / P^{Y}$} \\
\hline & China growth surge & 3.01 & 0.41 & 0.36 & 9.84 \\
\hline & China transition & 3.20 & 0.38 & 0.41 & 4.83 \\
\hline \multicolumn{6}{|l|}{ Real income $Y / P^{C}$} \\
\hline & China growth surge & 4.69 & 0.57 & 0.09 & -0.06 \\
\hline & China transition & 3.58 & 0.37 & 0.33 & 2.26 \\
\hline
\end{tabular}

a The combined shocks to the US, EU, Japan and China are first simulated on the presumption that expectations over price levels are neutral and that there is no US monetary response. Real exchange rate changes are observed and then injected as further shocks to expectations in a second simulation. This second simulation is conducted with China's growth surge shocks included and then, separately, with China's transition shocks. The results indicate the collective effects of the shocks and their dependence on the Chinese policy regime.

b The "moderate" financial integration parameters assumed are values of the elasticity of substitution between assets for each region, $\sigma_{i}^{I}$. These are US: 20, EU: 20, Japan: 15, China: 10, Australia: 20, Rest of World: 10. c Here the US monetary base is held fixed on the presumption that UMP has ceased and CMP continues to be constrained by the zero lower bound. The EU and Japan target their consumer price levels, raising them by two percentage points.

d When combined with the other regional shocks, China's monetary policy is assumed to target its consumer price level in the case of a continued growth surge (a continuation of the pre-GFC exchange rate targeting regime would yield excessive deflation, as suggested by the results in Table 6). In the case of the less expansionary transition, it is assumed that the target is to retain the original level of employment. This avoids what would otherwise be a contraction in Chinese labour demand.

e Real and nominal exchange rates are defined relative to the US.

Source: Simulations of the model described in the text. 
Table 8: Effects of the Combined Shocks, with US Monetary Expansion by UMP ${ }^{\mathrm{a}, \mathrm{b}}$

\begin{tabular}{|c|c|c|c|c|c|}
\hline \% changes & Chinese shocks & US & $\mathrm{EU}(26)$ & Japan & China \\
\hline \multicolumn{6}{|l|}{ Real bond yield, $r$} \\
\hline & China growth surge & -7.77 & -5.28 & -5.56 & -1.23 \\
\hline & China transition & -2.73 & -1.99 & -1.82 & 1.08 \\
\hline \multicolumn{6}{|c|}{ Consumer price level, $P^{C}$} \\
\hline & China growth surge & -0.24 & $2.00^{d}$ & $2.00^{d}$ & $0.00^{d}$ \\
\hline & China transition & 0.48 & $2.00^{d}$ & $2.00^{d}$ & 0.72 \\
\hline \multicolumn{6}{|c|}{ Producer price level, $P^{P}$} \\
\hline & China growth surge & $0.00^{d}$ & 2.13 & 1.82 & -5.83 \\
\hline & China transition & $0.00^{d}$ & 1.90 & 1.95 & -0.79 \\
\hline \multicolumn{6}{|l|}{ Monetary base, $M_{B}$} \\
\hline & China growth surge & 8.46 & 6.26 & 5.68 & 3.53 \\
\hline & China transition & 5.22 & 3.85 & 3.53 & 5.13 \\
\hline \multicolumn{6}{|c|}{ Exchange rate vs US\$, E } \\
\hline & China growth surge & $0.00^{\mathrm{e}}$ & -2.43 & -3.05 & -0.73 \\
\hline & China transition & $0.00^{\mathrm{e}}$ & -0.82 & -0.61 & 0.71 \\
\hline \multicolumn{6}{|c|}{ Real exchange rate, $e_{R}$} \\
\hline & China growth surge & $0.00^{\mathrm{e}}$ & -0.09 & -1.35 & -7.87 \\
\hline & China transition & $0.00^{\mathrm{e}}$ & 1.45 & 1.44 & 1.70 \\
\hline \multicolumn{6}{|l|}{ Real investment, $I / P^{P}$} \\
\hline & China growth surge & 8.63 & 0.16 & -2.14 & 8.22 \\
\hline & China transition & 5.40 & -1.63 & -3.60 & 3.75 \\
\hline \multicolumn{6}{|c|}{ Production employment, $L$} \\
\hline & China growth surge & 3.66 & 2.59 & 2.22 & 4.23 \\
\hline & China transition & 3.66 & 2.31 & 2.37 & $0.00^{d}$ \\
\hline \multicolumn{6}{|c|}{ Real output (GDP), $Y / P^{Y}$} \\
\hline & China growth surge & 3.66 & 0.45 & 0.39 & 10.67 \\
\hline & China transition & 3.66 & 0.41 & 0.42 & 4.83 \\
\hline \multicolumn{6}{|l|}{ Real income $Y / P^{C}$} \\
\hline & China growth surge & 4.04 & 0.98 & 0.27 & 2.85 \\
\hline & China transition & 3.08 & 0.61 & 0.41 & 5.03 \\
\hline
\end{tabular}

a The combined shocks to the US, EU, Japan and China are first simulated on the presumption that expectations over price levels are neutral and that there is a US UMP response that targets the producer price level. Real exchange rate changes are observed and then injected as further shocks to expectations in a second simulation. This second simulation is conducted with China's growth surge shocks included and then, separately, with China's transition shocks. The results indicate the collective effects of the shocks and their dependence on the Chinese policy regime.

b The "moderate" financial integration parameters assumed are values of the elasticity of substitution between assets for each region, $\sigma_{i}^{I}$. These are US: 20, EU: 20, Japan: 15, China: 10, Australia: 20, Rest of World: 10. c When combined with the other regional shocks, China's monetary policy is assumed to target its consumer price level in the case of a continued growth surge (a continuation of the pre-GFC exchange rate targeting regime would yield excessive deflation, as suggested by the results in Table 6). In the case of the less expansionary transition, it is assumed that the target is to retain the original level of employment. This avoids what would otherwise be a contraction in Chinese labour demand.

d The US monetary target is its producer price level and the EU and Japan target their consumer price level, raising by two percentage points.

e Real and nominal exchange rates are defined relative to the US.

Source: Simulations of the model described in the text. 
Table 9: Effects of the Combined Shocks, with US Monetary Expansion by CMP ${ }^{\mathrm{a}, \mathrm{b}}$

\begin{tabular}{|c|c|c|c|c|c|}
\hline \% changes & Chinese shocks & US & $\mathrm{EU}(26)$ & Japan & China \\
\hline \multicolumn{6}{|l|}{ Real bond yield, $r$} \\
\hline & China growth surge & -5.30 & -3.13 & -3.45 & 0.77 \\
\hline & China transition & -1.27 & -0.76 & -0.56 & 2.08 \\
\hline \multicolumn{6}{|c|}{ Consumer price level, $P^{C}$} \\
\hline & China growth surge & -0.70 & $2.00^{d}$ & $2.00^{d}$ & $0.00^{c}$ \\
\hline & China transition & 0.17 & $2.00^{d}$ & $2.00 d$ & 1.30 \\
\hline \multicolumn{6}{|c|}{ Producer price level, $P^{P}$} \\
\hline & China growth surge & $0.00^{d}$ & 1.91 & 1.72 & -6.33 \\
\hline & China transition & $0.00^{d}$ & 1.78 & 1.88 & -0.79 \\
\hline \multicolumn{6}{|l|}{ Monetary base, $M_{B}$} \\
\hline & China growth surge & 7.03 & 4.59 & 4.25 & 1.65 \\
\hline & China transition & 4.38 & 2.91 & 2.67 & 4.42 \\
\hline \multicolumn{6}{|c|}{ Exchange rate vs US\$, $E$} \\
\hline & China growth surge & $0.00^{\mathrm{e}}$ & -3.59 & -4.48 & -2.00 \\
\hline & China transition & $0.00^{\mathrm{e}}$ & -1.62 & -1.61 & -0.75 \\
\hline \multicolumn{6}{|c|}{ Real exchange rate, $e_{R}$} \\
\hline & China growth surge & $0.00^{\mathrm{e}}$ & -1.59 & -2.96 & -9.59 \\
\hline & China transition & $0.00^{\mathrm{e}}$ & 0.45 & 0.32 & 0.10 \\
\hline \multicolumn{6}{|l|}{ Real investment, $I / P^{P}$} \\
\hline & China growth surge & 11.65 & -1.18 & -2.88 & 6.20 \\
\hline & China transition & 7.49 & -2.35 & -3.96 & 2.57 \\
\hline \multicolumn{6}{|c|}{ Production employment, $L$} \\
\hline & China growth surge & 3.66 & 2.33 & 2.09 & 3.47 \\
\hline & China transition & 3.66 & 2.17 & 2.29 & $0.00^{c}$ \\
\hline \multicolumn{6}{|c|}{ Real output (GDP), $Y / P^{Y}$} \\
\hline & China growth surge & 3.66 & 0.41 & 0.37 & 10.46 \\
\hline & China transition & 3.66 & 0.38 & 0.40 & 4.83 \\
\hline \multicolumn{6}{|l|}{ Real income $Y / P^{C}$} \\
\hline & China growth surge & 4.57 & 0.66 & 0.14 & 2.08 \\
\hline & China transition & 3.44 & 0.44 & 0.32 & 4.33 \\
\hline
\end{tabular}

a The combined shocks to the US, EU, Japan and China are first simulated on the presumption that expectations over price levels are neutral and that there is a US CMP response that targets the producer price level. Real exchange rate changes are observed and then injected as further shocks to expectations in a second simulation. This second simulation is conducted with China's growth surge shocks included and then, separately, with China's transition shocks. The results indicate the collective effects of the shocks and their dependence on the Chinese policy regime.

b The "moderate" financial integration parameters assumed are values of the elasticity of substitution between assets for each region, $\sigma_{i}^{I}$. These are US: 20, EU: 20, Japan: 15, China: 10, Australia: 20, Rest of World: 10. c When combined with the other regional shocks, China's monetary policy is assumed to target its consumer price level in the case of a continued growth surge (a continuation of the pre-GFC exchange rate targeting regime would yield excessive deflation, as suggested by the results in Table 6). In the case of the less expansionary transition, it is assumed that the target is to retain the original level of employment. This avoids what would otherwise be a contraction in Chinese labour demand.

d The US monetary target is its producer price level and the EU and Japan target their consumer price level, raising by two percentage points.

e Real and nominal exchange rates are defined relative to the US.

Source: Simulations of the model described in the text. 
Table 10: Marginal Effects of the Chinese Transition from High Growth ${ }^{\mathrm{a}}$

\begin{tabular}{|c|c|c|c|c|c|}
\hline \% changes & Regional shocks & US & EU(26) & Japan & China \\
\hline \multicolumn{6}{|l|}{ Real bond yield, $r$} \\
\hline & Unilateral shocks & 0.95 & 0.54 & 0.89 & 5.21 \\
\hline & Collective shocks US $M_{B}$ fixed & 1.25 & 1.23 & 1.37 & 5.49 \\
\hline & Collective shocks US UMP & 5.04 & 3.29 & 3.74 & 2.31 \\
\hline & Collective shocks US CMP & 4.03 & 2.37 & 2.89 & 1.31 \\
\hline \multicolumn{6}{|l|}{ Monetary base, $M_{B}$} \\
\hline & Unilateral shocks & $0.00^{\mathrm{b}}$ & $0.00^{\mathrm{b}}$ & $0.00^{b}$ & 4.00 \\
\hline & Collective shocks US $M_{B}$ fixed & $0.00^{b}$ & $-0.96^{\mathrm{e}}$ & $-0.59^{\mathrm{e}}$ & 2.19 \\
\hline & Collective shocks US UMP & $-3.24^{e}$ & $-2.41^{e}$ & $-2.15^{e}$ & 1.59 \\
\hline & Collective shocks US CMP & $-2.65^{\mathrm{e}}$ & $-1.68^{e}$ & $-1.58^{\mathrm{e}}$ & 2.77 \\
\hline \multicolumn{6}{|l|}{ Exch rate vs US\$, E } \\
\hline & Unilateral shocks & $0.00^{c}$ & 1.10 & 2.59 & -0.88 \\
\hline & Collective shocks US $M_{B}$ fixed & $0.00^{c}$ & 2.88 & 3.73 & 0.48 \\
\hline & Collective shocks US UMP & $0.00^{c}$ & 1.61 & 2.44 & 1.43 \\
\hline & Collective shocks US CMP & $0.00^{c}$ & 1.97 & 2.87 & 1.24 \\
\hline \multicolumn{6}{|c|}{ Real exch rate vs US, $e_{R}$} \\
\hline & Unilateral shocks & $0.00^{c}$ & 0.88 & 2.60 & 8.27 \\
\hline & Collective shocks US $M_{B}$ fixed & $0.00^{c}$ & 2.30 & 3.53 & 9.19 \\
\hline & Collective shocks US UMP & $0.00^{c}$ & 1.54 & 2.79 & 9.57 \\
\hline & Collective shocks US CMP & $0.00^{c}$ & 2.04 & 3.28 & 9.69 \\
\hline \multicolumn{6}{|l|}{ Real investment, $I / P^{P}$} \\
\hline & Unilateral shocks & -1.15 & -0.63 & -0.82 & 0.27 \\
\hline & Collective shocks US $M_{B}$ fixed & -1.10 & -0.55 & -0.41 & -1.24 \\
\hline & Collective shocks US UMP & -3.23 & -1.79 & -1.46 & -4.47 \\
\hline & Collective shocks US CMP & -4.16 & -1.17 & -1.08 & -3.63 \\
\hline \multicolumn{6}{|l|}{ Real GDP, $Y / P^{Y}$} \\
\hline & Unilateral shocks & 0.14 & 0.11 & 0.10 & -5.57 \\
\hline & Collective shocks US $M_{B}$ fixed & 0.19 & -0.03 & 0.05 & -5.01 \\
\hline & Collective shocks US UMP & $0.00^{d}$ & -0.04 & 0.03 & -5.84 \\
\hline & Collective shocks US CMP & $0.00^{d}$ & -0.03 & 0.03 & -5.63 \\
\hline \multicolumn{6}{|l|}{ Real income, $Y / P^{C}$} \\
\hline & Unilateral shocks & -0.84 & -0.84 & 0.10 & 2.11 \\
\hline & Collective shocks US $M_{B}$ fixed & -1.11 & -0.20 & 0.24 & 2.32 \\
\hline & Collective shocks US UMP & -0.96 & -0.37 & 0.14 & 2.18 \\
\hline & Collective shocks US CMP & -1.13 & -0.22 & 0.18 & 2.25 \\
\hline
\end{tabular}

a This table compiles the differences between the results for the Chinese surge and its transition, in Tables 6-9, indicating the significance of this change of policy regime in the context of other global developments.

b Note that monetary policy is assumed to be stagnant due to the lower bound in these cases. The Chinese unilateral shocks of Table 6 are implemented with this assumption concerning the response of the US, the EU and Japan.

c Real and nominal exchange rates are defined relative to the US.

$\mathrm{d}$ In these cases, US monetary policy, by targeting the producer price level, restricts the change in US output to the same value, which depends on the US supply side shocks alone, irrespective of Chinese policy.

e These negative entries do not signify monetary contraction. They imply that the Chinese transition requires smaller monetary expansions in the US, the EU and Japan than the prior growth surge.

Source: Simulations of the model described in the text. 
Editor, UWA Economics Discussion Papers:

Sam Hak Kan Tang

University of Western Australia

35 Sterling Hwy

Crawley WA 6009

Australia

Email: ecoadmin@biz.uwa.edu.au

The Economics Discussion Papers are available at:

1980 - 2002: http://ecompapers.biz.uwa.edu.au/paper/PDF\%20of\%20Discussion\%20Papers/

Since 2001: http://ideas.repec.org/s/uwa/wpaper1.html

Since 2004: $\quad$ http://www.business.uwa.edu.au/school/disciplines/economics

\begin{tabular}{|c|c|c|}
\hline \multicolumn{3}{|c|}{$\begin{array}{l}\text { ECONOMICS DISCUSSION PAPERS } \\
2013\end{array}$} \\
\hline $\begin{array}{l}\text { DP } \\
\text { NUMBER }\end{array}$ & AUTHORS & TITLE \\
\hline 13.01 & $\begin{array}{l}\text { Chen, M., Clements, K.W. and } \\
\text { Gao, G. }\end{array}$ & THREE FACTS ABOUT WORLD METAL PRICES \\
\hline 13.02 & Collins, J. and Richards, O. & $\begin{array}{l}\text { EVOLUTION, FERTILITY AND THE AGEING } \\
\text { POPULATION }\end{array}$ \\
\hline 13.03 & $\begin{array}{l}\text { Clements, K., Genberg, H., } \\
\text { Harberger, A., Lothian, J., } \\
\text { Mundell, R., Sonnenschein, H. and } \\
\text { Tolley, G. }\end{array}$ & LARRY SJAASTAD, 1934-2012 \\
\hline 13.04 & Robitaille, M.C. and Chatterjee, I. & MOTHERS-IN-LAW AND SON PREFERENCE IN INDIA \\
\hline 13.05 & Clements, K.W. and Izan, I.H.Y. & $\begin{array}{l}\text { REPORT ON THE } 25^{\mathrm{TH}} \text { PHD CONFERENCE IN } \\
\text { ECONOMICS AND BUSINESS }\end{array}$ \\
\hline 13.06 & Walker, A. and Tyers, R. & QUANTIFYING AUSTRALIA’S “THREE SPEED” BOOM \\
\hline 13.07 & Yu, F. and Wu, Y. & PATENT EXAMINATION AND DISGUISED PROTECTION \\
\hline 13.08 & $\mathrm{Yu}, \mathrm{F}$. and $\mathrm{Wu}, \mathrm{Y}$. & $\begin{array}{l}\text { PATENT CITATIONS AND KNOWLEDGE SPILLOVERS: } \\
\text { AN ANALYSIS OF CHINESE PATENTS REGISTER IN } \\
\text { THE US }\end{array}$ \\
\hline 13.09 & Chatterjee, I. and Saha, B. & BARGAINING DELEGATION IN MONOPOLY \\
\hline 13.10 & Cheong, T.S. and Wu, Y. & $\begin{array}{l}\text { GLOBALIZATION AND REGIONAL INEQUALITY IN } \\
\text { CHINA }\end{array}$ \\
\hline 13.11 & Cheong, T.S. and Wu, Y. & INEQUALITY AND CRIME RATES IN CHINA \\
\hline 13.12 & Robertson, P.E. and Ye, L. & ON THE EXISTENCE OF A MIDDLE INCOME TRAP \\
\hline 13.13 & Robertson, P.E. & THE GLOBAL IMPACT OF CHINA’S GROWTH \\
\hline 13.14 & $\begin{array}{l}\text { Hanaki, N., Jacquemet, N., } \\
\text { Luchini, S., and Zylbersztejn, A. }\end{array}$ & $\begin{array}{l}\text { BOUNDED RATIONALITY AND STRATEGIC } \\
\text { UNCERTAINTY IN A SIMPLE DOMINANCE SOLVABLE } \\
\text { GAME }\end{array}$ \\
\hline 13.15 & $\begin{array}{l}\text { Okatch, Z., Siddique, A. and } \\
\text { Rammohan, A. }\end{array}$ & $\begin{array}{l}\text { DETERMINANTS OF INCOME INEQUALITY IN } \\
\text { BOTSWANA }\end{array}$ \\
\hline 13.16 & Clements, K.W. and Gao, G. & $\begin{array}{l}\text { A MULTI-MARKET APPROACH TO MEASURING THE } \\
\text { CYCLE }\end{array}$ \\
\hline
\end{tabular}




\begin{tabular}{|c|c|c|}
\hline 13.17 & Chatterjee, I. and Ray, R. & $\begin{array}{l}\text { THE ROLE OF INSTITUTIONS IN THE INCIDENCE OF } \\
\text { CRIME AND CORRUPTION }\end{array}$ \\
\hline 13.18 & Fu, D. and $\mathrm{Wu}, \mathrm{Y}$. & $\begin{array}{l}\text { EXPORT SURVIVAL PATTERN AND DETERMINANTS } \\
\text { OF CHINESE MANUFACTURING FIRMS }\end{array}$ \\
\hline 13.19 & Shi, X., Wu, Y. and Zhao, D. & $\begin{array}{l}\text { KNOWLEDGE INTENSIVE BUSINESS SERVICES AND } \\
\text { THEIR IMPACT ON INNOVATION IN CHINA }\end{array}$ \\
\hline 13.20 & $\begin{array}{l}\text { Tyers, R., Zhang, Y. and } \\
\text { Cheong, T.S. }\end{array}$ & $\begin{array}{l}\text { CHINA’S SAVING AND GLOBAL ECONOMIC } \\
\text { PERFORMANCE }\end{array}$ \\
\hline 13.21 & Collins, J., Baer, B. and Weber, E.J. & $\begin{array}{l}\text { POPULATION, TECHNOLOGICAL PROGRESS AND THE } \\
\text { EVOLUTION OF INNOVATIVE POTENTIAL }\end{array}$ \\
\hline 13.22 & Hartley, P.R. & THE FUTURE OF LONG-TERM LNG CONTRACTS \\
\hline 13.23 & Tyers, R. & $\begin{array}{l}\text { A SIMPLE MODEL TO STUDY GLOBAL } \\
\text { MACROECONOMIC INTERDEPENDENCE }\end{array}$ \\
\hline 13.24 & McLure, M. & $\begin{array}{l}\text { REFLECTIONS ON THE QUANTITY THEORY: PIGOU IN } \\
1917 \text { AND PARETO IN 1920-21 }\end{array}$ \\
\hline 13.25 & Chen, A. and Groenewold, N. & $\begin{array}{l}\text { REGIONAL EFFECTS OF AN EMISSIONS-REDUCTION } \\
\text { POLICY IN CHINA: THE IMPORTANCE OF THE } \\
\text { GOVERNMENT FINANCING METHOD }\end{array}$ \\
\hline 13.26 & Siddique, M.A.B. & $\begin{array}{l}\text { TRADE RELATIONS BETWEEN AUSTRALIA AND } \\
\text { THAILAND: } 1990 \text { TO } 2011\end{array}$ \\
\hline 13.27 & Li, B. and Zhang, J. & $\begin{array}{l}\text { GOVERNMENT DEBT IN AN INTERGENERATIONAL } \\
\text { MODEL OF ECONOMIC GROWTH, ENDOGENOUS } \\
\text { FERTILITY, AND ELASTIC LABOR WITH AN } \\
\text { APPLICATION TO JAPAN }\end{array}$ \\
\hline 13.28 & Robitaille, M. and Chatterjee, I. & $\begin{array}{l}\text { SEX-SELECTIVE ABORTIONS AND INFANT } \\
\text { MORTALITY IN INDIA: THE ROLE OF PARENTS' } \\
\text { STATED SON PREFERENCE }\end{array}$ \\
\hline 13.29 & Ezzati, P. & $\begin{array}{l}\text { ANALYSIS OF VOLATILITY SPILLOVER EFFECTS: } \\
\text { TWO-STAGE PROCEDURE BASED ON A MODIFIED } \\
\text { GARCH-M }\end{array}$ \\
\hline 13.30 & Robertson, P. E. & $\begin{array}{l}\text { DOES A FREE MARKET ECONOMY MAKE AUSTRALIA } \\
\text { MORE OR LESS SECURE IN A GLOBALISED WORLD? }\end{array}$ \\
\hline 13.31 & $\begin{array}{l}\text { Das, S., Ghate, C. and } \\
\text { Robertson, P. E. }\end{array}$ & $\begin{array}{l}\text { REMOTENESS AND UNBALANCED GROWTH: } \\
\text { UNDERSTANDING DIVERGENCE ACROSS INDIAN } \\
\text { DISTRICTS }\end{array}$ \\
\hline 13.32 & Robertson, P.E. and Sin, A. & $\begin{array}{l}\text { MEASURING HARD POWER: CHINA’S ECONOMIC } \\
\text { GROWTH AND MILITARY CAPACITY }\end{array}$ \\
\hline 13.33 & Wu, Y. & $\begin{array}{l}\text { TRENDS AND PROSPECTS FOR THE RENEWABLE } \\
\text { ENERGY SECTOR IN THE EAS REGION }\end{array}$ \\
\hline 13.34 & $\begin{array}{l}\text { Yang, S., Zhao, D., Wu, Y. and } \\
\text { Fan, J. }\end{array}$ & $\begin{array}{l}\text { REGIONAL VARIATION IN CARBON EMISSION AND } \\
\text { ITS DRIVING FORCES IN CHINA: AN INDEX } \\
\text { DECOMPOSITION ANALYSIS }\end{array}$ \\
\hline
\end{tabular}




\section{ECONOMICS DISCUSSION PAPERS}

2014

\begin{tabular}{|c|c|c|}
\hline $\begin{array}{l}\text { DP } \\
\text { NUMBER }\end{array}$ & AUTHORS & TITLE \\
\hline 14.01 & $\begin{array}{l}\text { Boediono, Vice President of the Republic } \\
\text { of Indonesia }\end{array}$ & $\begin{array}{l}\text { THE CHALLENGES OF POLICY MAKING IN A } \\
\text { YOUNG DEMOCRACY: THE CASE OF INDONESIA } \\
\text { (52ND SHANN MEMORIAL LECTURE, 2013) }\end{array}$ \\
\hline 14.02 & Metaxas, P.E. and Weber, E.J. & $\begin{array}{l}\text { AN AUSTRALIAN CONTRIBUTION TO } \\
\text { INTERNATIONAL TRADE THEORY: THE } \\
\text { DEPENDENT ECONOMY MODEL }\end{array}$ \\
\hline 14.03 & Fan, J., Zhao, D., Wu, Y. and Wei, J. & $\begin{array}{l}\text { CARBON PRICING AND ELECTRICITY MARKET } \\
\text { REFORMS IN CHINA }\end{array}$ \\
\hline 14.04 & McLure, M. & $\begin{array}{l}\text { A.C. PIGOU’S MEMBERSHIP OF THE } \\
\text { ‘CHAMBERLAIN-BRADBURY’ COMMITTEE. } \\
\text { PART I: THE HISTORICAL CONTEXT }\end{array}$ \\
\hline 14.05 & McLure, M. & $\begin{array}{l}\text { A.C. PIGOU'S MEMBERSHIP OF THE } \\
\text { 'CHAMBERLAIN-BRADBURY’ COMMITTEE. } \\
\text { PART II: ‘TRANSITIONAL’ AND ‘ONGOING' ISSUES }\end{array}$ \\
\hline 14.06 & King, J.E. and McLure, M. & HISTORY OF THE CONCEPT OF VALUE \\
\hline 14.07 & Williams, A. & $\begin{array}{l}\text { A GLOBAL INDEX OF INFORMATION AND } \\
\text { POLITICAL TRANSPARENCY }\end{array}$ \\
\hline 14.08 & Knight, K. & $\begin{array}{l}\text { A.C. PIGOU'S THE THEORY OF UNEMPLOYMENT } \\
\text { AND ITS CORRIGENDA: THE LETTERS OF } \\
\text { MAURICE ALLEN, ARTHUR L. BOWLEY, RICHARD } \\
\text { KAHN AND DENNIS ROBERTSON }\end{array}$ \\
\hline 14.09 & Cheong, T.S. and Wu, Y. & $\begin{array}{l}\text { THE IMPACTS OF STRUCTURAL RANSFORMATION } \\
\text { AND INDUSTRIAL UPGRADING ON REGIONAL } \\
\text { INEQUALITY IN CHINA }\end{array}$ \\
\hline 14.10 & $\begin{array}{l}\text { Chowdhury, M.H., Dewan, M.N.A., } \\
\text { Quaddus, M., Naude, M. and } \\
\text { Siddique, A. }\end{array}$ & $\begin{array}{l}\text { GENDER EQUALITY AND SUSTAINABLE } \\
\text { DEVELOPMENT WITH A FOCUS ON THE COASTAL } \\
\text { FISHING COMMUNITY OF BANGLADESH }\end{array}$ \\
\hline 14.11 & Bon, J. & $\begin{array}{l}\text { UWA DISCUSSION PAPERS IN ECONOMICS: THE } \\
\text { FIRST } 750\end{array}$ \\
\hline 14.12 & Finlay, K. and Magnusson, L.M. & $\begin{array}{l}\text { BOOTSTRAP METHODS FOR INFERENCE WITH } \\
\text { CLUSTER-SAMPLE IV MODELS }\end{array}$ \\
\hline 14.13 & Chen, A. and Groenewold, N. & $\begin{array}{l}\text { THE EFFECTS OF MACROECONOMIC SHOCKS ON } \\
\text { THE DISTRIBUTION OF PROVINCIAL OUTPUT IN } \\
\text { CHINA: ESTIMATES FROM A RESTRICTED VAR } \\
\text { MODEL }\end{array}$ \\
\hline 14.14 & Hartley, P.R. and Medlock III, K.B. & $\begin{array}{l}\text { THE VALLEY OF DEATH FOR NEW ENERGY } \\
\text { TECHNOLOGIES }\end{array}$ \\
\hline 14.15 & $\begin{array}{l}\text { Hartley, P.R., Medlock III, K.B., } \\
\text { Temzelides, T. and Zhang, X. }\end{array}$ & $\begin{array}{l}\text { LOCAL EMPLOYMENT IMPACT FROM COMPETING } \\
\text { ENERGY SOURCES: SHALE GAS VERSUS WIND } \\
\text { GENERATION IN TEXAS }\end{array}$ \\
\hline 14.16 & Tyers, R. and Zhang, Y. & $\begin{array}{l}\text { SHORT RUN EFFECTS OF THE ECONOMIC REFORM } \\
\text { AGENDA }\end{array}$ \\
\hline 14.17 & Clements, K.W., Si, J. and Simpson, T. & UNDERSTANDING NEW RESOURCE PROJECTS \\
\hline 14.18 & Tyers, R. & $\begin{array}{l}\text { SERVICE OLIGOPOLIES AND AUSTRALIA’S } \\
\text { ECONOMY-WIDE PERFORMANCE }\end{array}$ \\
\hline
\end{tabular}




\begin{tabular}{|c|c|c|}
\hline \multicolumn{3}{|c|}{$\begin{array}{l}\text { ECONOMICS DISCUSSION PAPERS } \\
2014\end{array}$} \\
\hline $\begin{array}{l}\text { DP } \\
\text { NUMBER }\end{array}$ & AUTHORS & TITLE \\
\hline 14.19 & Tyers, R. and Zhang, Y. & $\begin{array}{l}\text { REAL EXCHANGE RATE DETERMINATION AND } \\
\text { THE CHINA PUZZLE }\end{array}$ \\
\hline 14.20 & Ingram, S.R. & $\begin{array}{l}\text { COMMODITY PRICE CHANGES ARE } \\
\text { CONCENTRATED AT THE END OF THE CYCLE }\end{array}$ \\
\hline 14.21 & Cheong, T.S. and Wu, Y. & $\begin{array}{l}\text { CHINA'S INDUSTRIAL OUTPUT: A COUNTY-LEVEL } \\
\text { STUDY USING A NEW FRAMEWORK OF } \\
\text { DISTRIBUTION DYNAMICS ANALYSIS }\end{array}$ \\
\hline 14.22 & $\begin{array}{l}\text { Siddique, M.A.B., Wibowo, H. and } \\
\text { Wu, Y. }\end{array}$ & $\begin{array}{l}\text { FISCAL DECENTRALISATION AND INEQUALITY IN } \\
\text { INDONESIA: 1999-2008 }\end{array}$ \\
\hline 14.23 & Tyers, R. & $\begin{array}{l}\text { ASYMMETRY IN BOOM-BUST SHOCKS: } \\
\text { AUSTRALIAN PERFORMANCE WITH OLIGOPOLY }\end{array}$ \\
\hline 14.24 & Arora, V., Tyers, R. and Zhang, Y. & $\begin{array}{l}\text { RECONSTRUCTING THE SAVINGS GLUT: THE } \\
\text { GLOBAL IMPLICATIONS OF ASIAN EXCESS } \\
\text { SAVING }\end{array}$ \\
\hline 14.25 & Tyers, R. & $\begin{array}{l}\text { INTERNATIONAL EFFECTS OF CHINA’S RISE AND } \\
\text { TRANSITION: NEOCLASSICAL AND KEYNESIAN } \\
\text { PERSPECTIVES }\end{array}$ \\
\hline 14.26 & Milton, S. and Siddique, M.A.B. & $\begin{array}{l}\text { TRADE CREATION AND DIVERSION UNDER THE } \\
\text { THAILAND-AUSTRALIA FREE TRADE } \\
\text { AGREEMENT (TAFTA) }\end{array}$ \\
\hline 14.27 & Clements, K.W. and Li, L. & VALUING RESOURCE INVESTMENTS \\
\hline 14.28 & Tyers, R. & $\begin{array}{l}\text { PESSIMISM SHOCKS IN A MODEL OF GLOBAL } \\
\text { MACROECONOMIC INTERDEPENDENCE }\end{array}$ \\
\hline 14.29 & Iqbal, K. and Siddique, M.A.B. & $\begin{array}{l}\text { THE IMPACT OF CLIMATE CHANGE ON } \\
\text { AGRICULTURAL PRODUCTIVITY: EVIDENCE } \\
\text { FROM PANEL DATA OF BANGLADESH }\end{array}$ \\
\hline 14.30 & Ezzati, P. & $\begin{array}{l}\text { MONETARY POLICY RESPONSES TO FOREIGN } \\
\text { FINANCIAL MARKET SHOCKS: APPLICATION OF A } \\
\text { MODIFIED OPEN-ECONOMY TAYLOR RULE }\end{array}$ \\
\hline 14.31 & Tang, S.H.K. and Leung, C.K.Y. & $\begin{array}{l}\text { THE DEEP HISTORICAL ROOTS OF } \\
\text { MACROECONOMIC VOLATILITY }\end{array}$ \\
\hline 14.32 & Arthmar, R. and McLure, M. & $\begin{array}{l}\text { PIGOU, DEL VECCHIO AND SRAFFA: THE } 1955 \\
\text { INTERNATIONAL ‘ANTONIO FELTRINELLI’ PRIZE } \\
\text { FOR THE ECONOMIC AND SOCIAL SCIENCES }\end{array}$ \\
\hline 14.33 & McLure, M. & $\begin{array}{l}\text { A-HISTORIAL ECONOMIC DYNAMICS: A BOOK } \\
\text { REVIEW }\end{array}$ \\
\hline 14.34 & Clements, K.W. and Gao, G. & $\begin{array}{l}\text { THE ROTTERDAM DEMAND MODEL HALF A } \\
\text { CENTURY ON }\end{array}$ \\
\hline
\end{tabular}




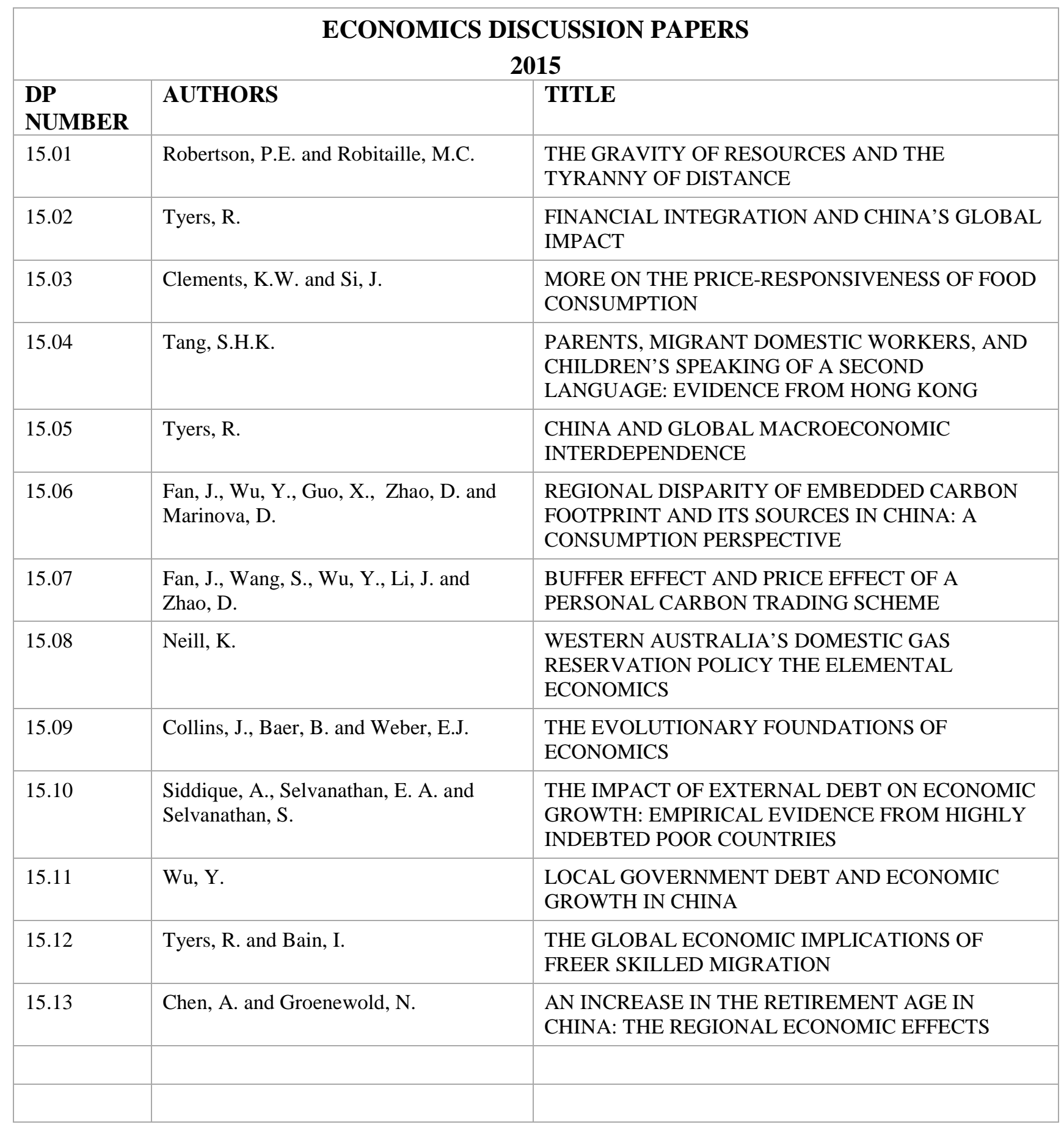

